\title{
Two new species of Pseudopimelodus Bleeker, 1858 (Siluriformes: Pseudopimelodidae) from the Magdalena Basin, Colombia
}

Ana M. Restrepo-Gómez ${ }^{\text {Equal first author, } 1 \text {, José D. Rangel-Medrano }}{ }^{\text {Equal first author, } 2 \text {, Edna J. Márquez }}{ }^{\text {Corresp., } 2}$, Armando OrtegaLara $^{3,4}$

1 Facultad de Ciencias Agrarias, Universidad Nacional de Colombia, Medellín, Antioquia, Colombia

2 Facultad de Ciencias, Laboratorio de Biología Molecular y Celular, Universidad Nacional de Colombia, Medellín, Antioquia, Colombia

3 Grupo de Investigación en Peces Neotropicales, Fundación para la Investigación y el Desarrollo Sostenible (FUNINDES), Cali, Colombia

4 Departamento de Biología, Facultad de Ciencias, Universidad del Valle, Cali, Colombia

Corresponding Author: Edna J. Márquez

Email address: ejmarque@unal.edu.co

The family Pseudopimelodidae is widely distributed in South America and includes 51 described species organized in seven genera. Only two of four species of the genus Pseudopimelodus have been recorded for the trans-Andean basins of Colombia, Pseudopimelodus bufonius and P. schultzi, whose similarity in external morphology make their identification difficult. We performed a phylogenetic analysis using a fragment of the Cytochrome C Oxidase subunit 1 gene (COI), and analyzed osteological and traditional morphometric characters to study Pseudopimelodus from the Colombian trans-Andean region. Results provided strong support for two clades phylogenetically related to Pseudopimelodus, that showed clear-cut molecular, osteological, and morphometric differences from previously described bumblebee catfishes. Based on these results, we describe two Pseudopimelodus species from the Magdalena-Cauca River Basin: P. magnus sp. nov. with 43 - 44 vertebrae, dorsal-fin spine with serrations on its anterior margin; lateral margin of transverse process of the fourth vertebra of the Weberian complex forming an acute angle in ventral view and $P$. atricaudus sp. nov. with 39 vertebrae, dorsal-fin spine smooth on its anterior margin and a dark, vertical band covering $3 / 4$ of the caudal fin with base of rays and tip of caudal-fin lobes hyaline. 
1 Two new species of Pseudopimelodus Bleeker, 1858 (Siluriformes: Pseudopimelodidae) from the

2 Magdalena Basin, Colombia

3

4 Ana M. Restrepo-Gómez¹, José D. Rangel-Medrano², Edna J. Márquez², Armando Ortega-Lara ${ }^{3,4}$

5

6

$7 \quad{ }^{1}$ Facultad de Ciencias Agrarias, Universidad Nacional de Colombia, Medellín, Antioquia, Colombia.

8

$9 \quad{ }^{2}$ Facultad de Ciencias, Laboratorio de Biología Molecular y Celular, Universidad Nacional de Colombia, 10 Medellín, Antioquia, Colombia.

11

$12{ }^{3}$ Grupo de Investigación en Peces Neotropicales, Fundación para la Investigación y el Desarrollo

13 Sostenible (FUNINDES), Cali, Colombia.

14

15

${ }^{4}$ Departamento de Biología, Facultad de Ciencias, Universidad del Valle, Cali, Colombia.

16

17 Author correspondence: Edna. J. Márquez, Carrera 65 No. 59A - 110 Bloque 19 A Laboratorio 310,

18 Medellín, 050034 Colombia, ejmarque@unal.edu.co; ejmarque@gmail.com.

19

20

21

22 


\section{Abstract}

24 The family Pseudopimelodidae is widely distributed in South America and includes 51 described species 25 organized in seven genera. Only two of four species of the genus Pseudopimelodus have been recorded 26 for the trans-Andean basins of Colombia, Pseudopimelodus bufonius and P. schultzi, whose similarity in 27 external morphology make their identification difficult. We performed a phylogenetic analysis using a 28 fragment of the Cytochrome C Oxidase subunit 1 gene (COI), and analyzed osteological and traditional 29 morphometric characters to study Pseudopimelodus from the Colombian trans-Andean region. Results 30 provided strong support for two clades phylogenetically related to Pseudopimelodus, that showed clear31 cut molecular, osteological, and morphometric differences from previously described bumblebee 32 catfishes. Based on these results, we describe two Pseudopimelodus species from the Magdalena-Cauca 33 River Basin: P. magnus sp. nov. with 43 - 44 vertebrae, dorsal-fin spine with serrations on its anterior 34 margin; lateral margin of transverse process of the fourth vertebra of the Weberian complex forming an 35 acute angle in ventral view and $P$. atricaudus sp. nov. with 39 vertebrae, dorsal-fin spine smooth on its 36 anterior margin and a dark, vertical band covering $3 / 4$ of the caudal fin with base of rays and tip of caudal37 fin lobes hyaline. 


\section{Introduction}

40 The order Siluriformes is a highly diverse group encompassing at least 3975 valid species (Fricke,

41 Eschmeyer \& Fong, 2020) and a growing number of new species are being described (Shibatta, 2016; Ruiz,

42 2016; Shibatta \& Vari, 2017; Shibatta, 2019; Tobes et al., 2020). Within this order, Pseudopimelodidae

43 (Bumblebee catfishes) is a small monophyletic family of Neotropical catfishes, broadly distributed across

44 different river basins in South America, from the Atrato River in Colombia to the Río de la Plata in 45 Argentina (Ferraris, 2007) and it is considered one of the least known families among the Neotropical 46 freshwater catfishes (Shibatta, 2013).

47 Members of Pseudopimelodidae were originally included in family Pimelodidae; furthermore, Lundberg,

Bornbusch \& Mago-Leccia (1991) demonstrated its monophyly based on several synapomorphies, and its family rank was proposed by Shibatta (2003). These synapomorphies include: 1) lack of spike-like membranous wings of bone projecting beyond the palatine condyle on the lateral ethmoid; 2) a short metapterygoid, broader (at least twice) than long, deflected inward and usually subtended by a ridge or only narrowly separated (Microglanis), and 5) absence of dorsal hypohyals.

57 In a phylogenetic analysis based on 440 characters and 87 taxa representing all extant catfish families,

58 Diogo, Chardon \& Vandewalle (2004) confirmed the above mentioned synapomorphies and described two 59 additional features: 1) a markedly bifurcated mesethmoid and 2) a spoon-shaped autopalatine with a 60 roundish, dorso-ventrally expanded posterior tip. Subsequent molecular studies based on mitochondrial and 61 nuclear gene sequences (Hardman, 2005; Sullivan, Lundberg \& Hardman, 2006; Lundberg, Sullivan \& 62 Hardman, 2011; Sullivan, Muriel-Cunha \& Lundberg, 2013) showed that the family Pseudopimelodidae 63 forms a well-supported monophyletic assemblage along with Heptapteridae, Pimelodidae, and Phreatobius. 
64 In addition to the above-mentioned synapomorphies, five additional characters were proposed for the family

65 Pseudopimelodidae (Shibatta \& Vari, 2017).

66 Until very recently, six genera including at least 51 species were recognized in Pseudopimelodidae:

67 Batrochoglanis Gill, 1858; Cephalosilurus Haseman, 1911; Cruciglanis Ortega-Lara \& Lehmann, 2006;

68 Lophiosilurus Steindachner, 1876; Microglanis Eigenmann, 1912; and Pseudopimelodus Bleeker, 1858

69 (Fricke, Eschmeyer \& Fong, 2020). Shibatta \& Vari (2017) described Rhyacoglanis from cis-Andean South

70 America, comprising four new species and Pseudopimelodus pulcher Boulenger, 1887, from the Western

71 Amazon Basin as the type species.

72 So far, records in Colombia include a total of six of the seven formally recognized genera of

73 Pseudopimelodidae and only two of the four species of Pseudopimelodus (DoNascimiento et al., 2017).

74 Although it was thought that the species P. bufonius (Valenciennes, 1840) and P. schultzi (Dahl, 1955) had

75 overlapping distribution ranges in the Magdalena-Cauca River Basin, in a recently published checklist

76 (DoNascimiento et al., 2017), the presence of P. bufonius was restricted to the Amazon, Orinoco and

77 Caribbean basins, while the species P. schultzi was restricted to both the Magdalena-Cauca and Caribbean

78 basins, including the Sinú River, type locality of this species.

79 In addition to the difficulties to define their distribution, a phylogeographic study revealed the presence of

80 five separate evolutionary lineages of Pseudopimelodus in trans- and cis-Andean rivers of Colombia

81 (Rangel-Medrano, Ortega-Lara \& Marquez, 2020). Thus, to test the hypothesis that undescribed species are

82 currently classified in Colombia under the names $P$. schultzi and $P$. bufonius, this study integrated molecular

83 and morphological analyses, including osteology and external morphology, to address the taxonomic status

84 of Pseudopimelodus species inhabiting the Magdalena-Cauca River Basin. Results identified two new

85 species of the family Pseudopimelodidae from northwestern South America, both described in this study.

86

\section{Material and Methods}

88 Material studied

Peer] reviewing PDF | (2018:07:29459:3:0:NEW 18 Jul 2020) 
89 The material examined is deposited in museums and institutions as described below and institutional

90 abbreviations used in the present study are listed in Sabaj (2019).

91 Pseudopimelodus bufonius: Guyana: Upper Essequibo River Basin: Takutu River: AUM 38248, 1, 72.3

92 mm SL; Rupunini River: AUM 38292, cleared and stained (C\&S) specimen, 58.6 mm SL; AUM 48352, 1,

9374.3 mm SL; Potaro-Siparuni: AUM 45384, 1, 87.6 mm SL. Colombia: Upper Amazon River Basin:

94 Vaupés River: IMCN 8230, 5, 137.4 - 221.7 mm SL. Orinoco River Basin: Upper Meta River Drainage:

95 Negro River: IMCN 8231, 13, 118.3 - 191.0 mm SL. Venezuela: Orinoco River Basin: Apure River

96 Drainage: Bocono River: MCNG 5307, 4, 103.4 - 123.5 mm SL.

97 Pseudopimelodus schultzi: Colombia: Sinú River: IMCN 8241, 12 (2 C\&S), 174 - 305 mm SL.

98 Pseudopimelodus mangurus: Argentina: Upper La Plata River Basin: Paraná River: IMCN 8441, 2,

$99 \quad 117.7-137.9 \mathrm{~mm} \mathrm{SL}$.

100 Pseudopimelodus charus: Brazil: Sao Francisco river drainage: LBP10489, 1, 123.1 mm SL; LBP 11308,

$1011,154.5 \mathrm{~mm}$ SL.

102 In addition, the morphological comparisons with Pseudopimelodus charus were based on the figure of

103 Valenciennes published in Mees (1974).

104

105 Phylogenetic analyses

106 Phylogenetic analysis was conducted with MrBayes (MB) v3.2 (Ronquist et al., 2012) using COI haplotype 107 sequences from Pseudopimelodus specimens (Table 1), belonging to lineages 1 and 5 described by Rangel108 Medrano, Ortega-Lara \& Márquez (2020). Haplotypes were compared with GenBank COI sequences of 109 remaining members of the family Pseudopimelodidae (Table1), using HKY $+\mathrm{G}$ as the best-fit evolutionary 110 model estimated in IQ-TREE software (Kalyaanamoorthy et al., 2017). Two Pimelodid species (Pimelodus 111 yuma and Pseudoplatystoma magdaleniatum) were used as outgroups. Chain parameters included two 112 independent Markov Chain Monte Carlo (MCMC) iterations for 20 million generations sampled every 1000 113 generations, discarding the first $25 \%$ sampled generations as burn-in; remaining parameters were left as

114 default. Convergence of the MCMC was assessed based on the Potential Scale Reduction Factor which 
115 should approach 1.0 as runs converge and considering the standard deviation of split frequencies which

116 should approach 0 . Trees were summarized according to their estimated posterior probability to produce a

117 consensus tree, using the same burn-in as the MCMC. The final tree was visualized with the program

118 FigTree v1.4.2 (Rambaut, 2014). Nodes were considered well supported with posterior probabilities $\geq 0.95$

119 (Wilcox et al., 2002). Finally, following the DNA barcoding of freshwater fishes (Hubert et al., 2008), the

120 pair-wise divergences of Pseudopimelodus haplotype sequences was estimated using the Kimura 2

121 parameter model in MEGA v6.06 (Tamura et al., 2013).

122

123 Morphological analyses

124 Measurements followed standard procedures of Shibatta \& Vari (2017) using dial calipers to $0.1 \mathrm{~mm}$ on

125 the left side of specimens. Standard length is expressed in mm. Except for subunits of the head which are

126 expressed as percentages of head length, all measurements are expressed as percentages of standard length.

127 Counts were made on the left side of the body when possible. Counts of dorsal, pectoral, pelvic, and anal

128 fin rays, as well as principal and procurrent caudal-fin rays were taken from dried skeletons (DS), cleaned

129 using dermestid beetles, C\&S specimens following Taylor \& Van Dyke (1985) and radiographs (RX) of

130 paratypes. Vertebral counts include the five fused vertebrae of the Weberian apparatus and one single

131 element of the compound caudal centrum (pleural $1+$ ural 1 centrum). Length of the posterior process of

132 cleithrum was measured from dorsal origin to its posterior end. Width of the pectoral-fin spine was

133 measured at its base. Length of the Weberian complex was measured in ventral view, longitudinally from

134 anterior to posterior mesial ends of centrum and was related to the length of the neurocranium, which was

135 measured from the mesial anterior margin of the mesethmoid to posterior margin of the basioccipital.

136 Osteological nomenclature follows Arratia (2003a, b).

137 The electronic version of this article in Portable Document Format (PDF) will represent a published work

138 according to the International Commission on Zoological Nomenclature (ICZN), and hence the new names

139 contained in the electronic version are effectively published under that Code from the electronic edition

140 alone. This published work and the nomenclatural acts it contains have been registered in ZooBank, the

Peer] reviewing PDF | (2018:07:29459:3:0:NEW 18 Jul 2020) 
141 online registration system for the ICZN. The ZooBank LSIDs (Life Science Identifiers) can be resolved

142 and the associated information viewed through any standard web browser by appending the LSID to the

143 prefix http://zoobank.org/. The LSID for this publication is: urn:lsid:zoobank.org:pub: 8B78D766-07A3-

144 47A8-A12C-F55958703ACB. The online version of this work is archived and available from the following

145 digital repositories: PeerJ, PubMed Central and CLOCKSS.

146

147 Results

148 Molecular analysis

149 Phylogenetic tree based on Bayesian Inference (Fig. 1), showed well-supported clades corresponding to 150 samples here proposed as new species (Pseudopimelodus magnus and P. atricaudus). Pseudopimelodus

151 magnus was recovered sister to P. schultzi from the Sinú River (H25 and H26) and both clades along with

152 P. bufonius from the Orinoco, appear as the sister-clade to P. bufonius, P. mangurus, and P. charus. In

153 contrast, P. atricaudus is sister to the remaining Pseudopimelodus species analyzed.

154 Kimura 2 parameters genetic distance was relatively small for $P$. atricaudus $(0.003-0.006)$, P. magnus

155 (0.003-0.020), and P. schultzi (0.020), whereas was larger between P. bufonius samples $(0.011-0.068)$.

156 The smallest Kimura 2 parameters genetic distance was observed between $P$. bufonius from Orteguaza

157 and $P$. mangurus (0.026), whereas the largest genetic distance was observed between $P$. schultzi and $P$.

158 atricaudus (0.113).

159

160 Pseudopimelodus magnus, sp. nov. (Fig. 2)

161 Pseudopimelodus bufonius [not Valenciennes, 1840]. — Steindachner, 1880: 59 [Cauca River; description].

162 — Miles, 1947: 64 [Magdalena River Basin; check list]. — Dahl, 1971: 54 [Magdalena River Basin; check

163 list]. - Maldonado-Ocampo et al., 2005: 159 Fig. 150 [Magdalena-Cauca River basin; check list].

164 Pseudopimelodus schultzi [not Dahl, 1955]. - Ortega-Lara et al., 2006: 49 [upper Cauca Basin; check

165 list]. — Ortega-Lara et al., 2011: 447 [fishery: Magdalena River Basin].

Peer] reviewing PDF | (2018:07:29459:3:0:NEW 18 Jul 2020) 
166

167 168

Pseudopimelodus zungaro [not Humboldt, 1833]. — Eigenmann \& Eigenmann, 1890: 112 [Goiás,

Brazil]. — Eigenmann, 1922: 32 [in part, Magdalena-Cauca River Basin; identification key].

Holotype. CIUA 5142, 750 mm SL, Colombia, Antioquia, Magdalena River Basin, Cauca River in Venecia, 6³9’47.6” N, 7550’9” W, Feb 2018, Restrepo-Gómez A.M.

Paratypes. ANDES I210, 2, 232.9 - 248.5 mm SL, Colombia, Antioquia, Magdalena River Basin, Cauca River in Venecia, 6³9’47.6” N, 7550’9.5” W, Feb 2016, Restrepo-Gómez A.M. CIUA 5163, 1, 531.7 mm SL, Colombia, Antioquia, Magdalena River Basin, Cauca River in Venecia, 6³9’47.6” N, 7550’9” W, Nov 2014, Olaya G. CP-UCO 3860, 1, 217.7 mm SL, Colombia, Antioquia, Magdalena River Basin, Cauca River in Venecia, 6³9’47.6” N, 7550’9” W, Nov 2015, Restrepo-Gómez A.M. CP-UCO 3861, 1 230.1 mm SL, Colombia, Bolívar, Magdalena River Basin, Cauca River in Achí, 8³4’8.1” N, 74³3'10.9” W, Oct 2015, Restrepo-Gómez A.M. CP-UCO 3862, 1, 177.9 mm SL, Colombia, Antioquia, Magdalena River Basin, Cauca River in Venecia, 6³9’47.6” N, 7550’9” W, Feb 2016, Restrepo-Gómez A.M. ICN-MHN 24386, 1, 326.84 mm SL, Colombia, Antioquia, Magdalena River Basin, Cauca River in Venecia, 6³9’47.6” N, 7550’9.5” W, Dec 2015, Restrepo-Gómez A.M. IMCN 0060, 1, 106 mm SL, Colombia, Valle del Cauca, Upper Cauca River Basin, Cauca River in Tuluá town, ca 46’55” N, 76¹7’47” W, Nov 1995, Victoria P. IMCN 0285, 1, 228 mm SL, Colombia, Cauca, Upper Cauca River Basin, Ovejas River in Suárez, ca. 257’41” N, 7640’39” W, Nov 1995, Usma S. IMCN 2349, 2 DS, 157.4 - 408 mm SL, Colombia, Cauca, Upper Cauca River Basin, Cauca River in El Hormiguero, Municipality of Puerto Tejada, ca. $3^{\circ} 18^{\prime} 05^{\prime \prime}$ N, $76^{\circ} 28^{\prime} 39^{\prime}$ ' W, 5 Nov 2002, Ortega-Lara A. IMCN 3885 , 2, 57.3 - 62.5 mm SL, Colombia, Valle del Cauca, Upper Cauca River Basin, La Vieja River in Cartago town, ca. $4^{\circ} 45^{\prime} 48^{\prime \prime} \mathrm{N}, 75^{\circ} 55^{\prime} 27^{\prime}$ ' W, 31 Aug 2004, Ortega-Lara A. IMCN 8234, 6, 1 DS, 268.1 - 340 mm SL, Colombia, Huila, Magdalena River Basin, Magdalena River in El Quimbo dam, Municipality of Garzón, ca. 2¹1'05” N, 75³9’44” W, 29 Aug 2015, Ortega-Lara A. IMCN 8239, 1 C\&S, not measured, Colombia, Cauca, Cauca River Basin, Cauca River in El Hormiguero, Municipality of Puerto tejada, $c a$. $3^{\circ} 18^{\prime} 25^{\prime \prime}$ N, 76²8’26” W, 1 Mar 2003, Ortega-Lara A. IMCN 8265, 1 DS, 213.7 mm SL, Colombia, 
192 Antioquia, Magdalena River Basin, Cauca River in Venecia, 6³9’ 47.6” N, 7550’9” W, Feb 2016,

193 Restrepo-Gómez A.M. IMCN 8267, 1 DS, 193.3 mm SL, Colombia, Antioquia, Magdalena River Basin, 194 Cauca River in Venecia, 6³9’47.61” N, 7550’9” W, Feb 2016, Restrepo-Gómez A.M. IMCN 8269, 1 195 RX, 217 mm SL, Colombia, Antioquia, Magdalena River Basin, Cauca River, Valdivia stream in Puerto 196 Valdivia, 7¹7’17.7” N, 75²3’32.1” W, Feb 2015, Olaya G. IMCN 8270, 1 RX, 294.2 mm SL,

197 Colombia, Antioquia, Magdalena River Basin, Cauca River in Venecia, 6³9’47.61” N, 7550’9” W, Apr 198 2015, Olaya G. IMCN 8939, 16, 171 - 475 mm SL, Colombia, Cauca, Upper Cauca River Basin, Cauca 199 River in El Hormiguero, Municipality of Puerto Tejada, ca. 3¹8'05” N, 76²8’39” W, 22 Dic 2011, 200 Ortega-Lara A.

201

202

203

Non-type material

204

CIUA 405, 53.8 mm SL Colombia, Valle del Cauca, Cauca River Basin, La Vieja River, 441'9.8” N, 205 7550'57.7’ W, Aug 2006, Ochoa L., Montoya A.F. CIUA 512, 160 mm SL, Colombia, Antioquia, 206 Cauca River Basin, Cauca River in Bolombolo, 558’01.3” N, 7550’26.5” W, Aug 2006, Ochoa L., 207 Montoya A.F.

208

209 Diagnosis. Pseudopimelodus magnus differs from its congeners by the total number of vertebrae (43 - 44, 210 Fig. $3 a$ vs. 39 in P. atricaudus Fig. 3b; 38 in P. bufonius; 38 - 40 in P. mangurus; 41 in P. schultzi) and 211 by the deeply acute notch on lateral margins of transverse process of the fourth vertebra of the Weberian 212 complex (Fig. 4a vs. shallowly concave in P. atricaudus, P. bufonius, P. mangurus, P. schultzi). It differs 213 from $P$. atricaudus by the angle of $<90^{\circ}$ formed by the medial junction of the posterior arm of the 214 transverse process of the fourth vertebra (Figs. 4 and $5 v s$. angle almost right). It differs from $P$. 215 atricaudus and P. mangurus by length ratio of Weberian complex and neurocranium $(32.1-36.3 \%$, Fig. 2165 vs. $46.9-55.5$ in P. atricaudus and $42.7 \%$ in P. mangurus). It differs from P. atricaudus, P. bufonius, 217 and P. mangurus by having shorter maxillary barbels, not surpassing the opercular margin (vs. reaching). 
218 Additionally, P. magnus differs from the remaining species, except $P$. atricaudus, by the length of the

219 posterior process of cleithrum (1.32 - 1.59 times the wide of the pectoral-fin spine base $v s .0 .57-0.75$ in

220 P. bufonius, $2.22-2.76$ in P. schultzi, $2.24-2.30$ in P. mangurus). It differs from P. bufonius, P. charus,

221 and P. mangurus by having a heart-shaped gas bladder (vs. dumbbell-shaped bladder; Fig. 6; Shibatta \&

222 Vari, 2017). It differs from $P$. atricaudus by having the anterior margin of the dorsal-fin spine serrated

223 (vs. smooth). Pseudopimelodus magnus differs from congeners except P. bufonius and P. schultzi by

224 having a narrow vertical dark band along the center of caudal fin, although in some specimens is hardly

225 visible ( $v s$. broad vertical dark band covering $\leq 1 / 2$ caudal fin in $P$. charus and $P$. mangurus or $3 / 4$ of the

226 caudal fin with base of rays and tip of caudal-fin lobes hyaline in P. atricaudus).

227

228 Description. Morphometric data in Table 2. Body depressed from snout tip to dorsal-fin origin;

229

230

231

232

233

234

235

236

237

238

239

240

241

242

243 progressively compressed towards caudal-fin base. Snout rounded in dorsal view. Head trapezoidal, depressed, slightly longer than wide. Head covered by thick skin hiding fontanel and cranial roof bones. premaxilla laterally projected backwards and reaching lateral process of lateral ethmoid. Anterior nostril tubular located lateroposteriorly to maxillary barbel base (Fig. 2). Posterior nostril equidistant from anterior nostril and eye. Maxillary barbel not reaching opercular margin. Mental barbel anteriorly inserted to gular apex. Inner mental barbel reaching gular apex. Outer mental barbel not reaching branchial opening. Gular fold V-shaped, with conspicuously pointed apex (Fig. 2). Branchiostegal membrane free from isthmus. Posterior process of vomer bifurcated. Posterior process of cleithrum triangular, its length 1.25 - 1.59 times width of pectoral-spine base. Vomer T-shaped, in contact with parasphenoid, mesethmoid, and lateral ethmoid. Posterior region of mesethmoid wider than base of parietosupraoccipital process (Fig. 5a). Transverse process of fourth vertebra of Weberian complex forming an angle $>90^{\circ}$ between anterior and lateral margins and $<90^{\circ}$ between lateral and posterior margins, in ventral view (Fig. 4). Length of Weberian complex in relation to length of neurocranium $32.2-36.3 \%$.

Anterior fontanel elongated, not reaching transverse line through opening of infraorbital sensory canal in 
244 sphenotic. Posterior fontanel small and oval-shaped, located at center of parieto-supraoccipital (Fig. 5a).

245 Parieto-supraoccipital process with bifurcated tip in contact with supraneural (Fig. 5a). Heart-shaped gas

246 bladder (Fig. 6). Lateral line complete, reaching caudal-fin base. Number of total vertebrae $43-44$. Ribs

247 13. Axillary pore present. Dorsal-fin origin at anterior third of body. Posterior margin of fin convex.

248 Dorsal-fin spine strongly ossified with distal end pointed, shorter than next branched ray and with

249 serrations on anterior margin. Dorsal-fin rays I, 6. Adipose-fin origin anterior to anal-fin origin. Pectoral-

250 fin spine serrated, covered by skin; anterior margin with $18-41$ serrations of similar size and posterior

251 margin with 17 - 27 larger serrations. Posterior edge of pectoral fin convex. Axillary pore present.

252 Pectoral-fin rays I, 7. Posterior margin of pelvic fin rounded; origin inserted behind posterior end of

253 dorsal-fin base. Pelvic-fin rays i, 5. Anal fin with posterior edge rounded and inserted below 20th

254 vertebra. Anal-fin rays iii, 7. Caudal fin bifurcated, with pointed lobes, upper lobe slightly narrower and

255 longer than ventral lobe. Caudal-fin rays i, 8, 7, i; dorsal procurrent rays 14; ventral procurrent rays 14.

256

257 Color in life and alcohol. Background of body of variable color from yellow to light brown with four

258 vertical dark bands (Fig. 7). First predorsal band partially cojoined with subdorsal band at level of upper

259 corner of branchial margin. Subdorsal band connected dorsally with sub-adipose band, almost reaching

260 anal-fin base. Dark band on caudal-fin base, completely fused or separated from sub-adipose band in

261 dorsal region. In some specimens, bands less evident and faint. Region between bands with small,

262 scattered and irregularly-shaped spots. Body covered by bright yellow mucus. Pectoral, ventral, and

263 dorsal fins reddish with two transverse dark bands, at base and last-third of each fin. Adipose-fin of same

264 color as body, occasionally covered by sub-adipose band in middle region. Caudal fin pale brown with or

265 without narrow dark band along the center of caudal fin. Color in alcohol (Fig. 2) similar to live

266 coloration, except regions lacking superficial mucus, becoming darker (grey to brown).

267

268 Distribution. Magdalena River, from upper sector at El Quimbo dam to the confluence with the Gualí

269 River in Honda town. Cauca River throughout the entire basin (Fig. 8).

Peer] reviewing PDF | (2018:07:29459:3:0:NEW 18 Jul 2020) 
270

271 Etymology. The specific name magnus is from the Latin, meaning "great" and refers to the fact that is the 272 largest species of Pseudopimelodus described so far (see Shibatta, 2003; Ortega-Lara, 2012; de Oliveira et 273 al., 2015; Vicentin, Silva-Ferreira \& Rondón-Suarez, 2019).

274

275

276

277

278

279

280

281

282

283

284

285

286

287

288

289

290

291

292

293

294

295

\section{Pseudopimelodus atricaudus, sp. nov. (Fig. 9)}

Pseudopimelodus schultzi [not Dahl, 1955]. — Ortega-Lara \& Lehmann, 2006: 155 [Magdalena Basin; comparative material]. — Mojica et al. 2006: 33 [middle Magdalena basin; check list]. — Villa-Navarro et al., 2006: 15 [upper Magdalena basin; check list].

Pseudopimelodus cf. bufonius [not Valenciennes, 1840): - Jiménez-Segura \& Ortega-Lara, 2011: 545 [Magdalena River Basin; fisheries].

Holotype. CIUA 5141, 143.7 mm SL, Colombia, Sucre, Magdalena River Basin, Cauca River in Guaranda, 8¹9’04.6” N, 74³1’56.9” W, Feb 2018, Restrepo-Gómez A.M.

Paratypes. ANDES I211, 1, 185.3 mm SL, Colombia, Antioquia, Magdalena River Basin, Cauca River in Barrio Chino, Caucasia, 800’35.2” N, 7500’0” W, Dec 2015, Restrepo-Gómez A.M. ANDES I212, 1, 203.5 mm SL, Colombia, Antioquia, Magdalena River Basin, Cauca River in Paloma, Caucasia, 759’31.7’” N, 7458'35.6” W, Dec 2015, Restrepo-Gómez A.M. CIUA 5159, 1, 241.0 mm SL, Colombia, Antioquia, Magdalena River Basin, Cauca River in Barrio Chino, Caucasia, 0800’35.3” N, 750’00” W, Dec 2015, Restrepo-Gómez A.M. CIUA 5160, 1, 190.0 mm SL, Colombia, Antioquia, Magdalena River Basin, Cauca River in La Ilusión, Caucasia, 8¹'50” N, 750’0.9” W, Dec 2015, Restrepo-Gómez A.M. CIUA 5161, 1, 205.0 mm SL, Colombia, Bolívar, Magdalena River Basin, Cauca River in Punta Cartagena, Pinillos, 853'37.3” N, 74²8'28.4” W, Feb 2014, Olaya G. CIUA 5162, 1, 250.0 mm SL, Colombia, Antioquia, Magdalena River Basin, Cauca River in Venecia, 6³9'47.6” N, 7550'9” W, Dec 2015, Olaya G. CP-UCO 3857, 3, 131.8 -198.9 mm SL, Colombia, Antioquia, Magdalena River Basin, Cauca River in Barrio Chino,

Peer] reviewing PDF | (2018:07:29459:3:0:NEW 18 Jul 2020) 
296 Caucasia, 80’35.3” N, 750’0” W, Dec 2015, Restrepo-Gómez A.M. CP-UCO 3858, 3, 153.8 - 192.6 mm 297 SL, Colombia, Bolívar, Magdalena River Basin, Cauca River in Punta Cartagena, Pinillos, 853’37.3” N, 298 74²8’28.4” W, Jan 2015, Olaya G. CP-UCO 3859, 1, 109.0 mm SL, Colombia, Bolívar, Magdalena River 299 Basin, Caribona River in Montecristo, 8¹9’6.1” N, 74³1’7.9” W, Dec 2015, Restrepo-Gómez A.M. 300 CZUT-IC 1785, 2, 136 - 178 mm SL, Colombia, Tolima, Magdalena River Basin, Magdalena River in 301 Honda, 5¹4’05” N, 7443’43” W, 15 Jan 2005. ICN-MHN 24387, 1, 147.9 mm SL, Colombia, Bolívar, 302 Magdalena River Basin, Cauca River in Punta Cartagena, Pinillos, 853’37.3” N, 74²8’28.4” W, Jan 2015, 303 Olaya G. IMCN 0324, 2, 139.7 - 185.3 mm SL, Colombia, Santander, Magdalena River Basin, Magdalena 304 River in Puerto Wilches, ca. 7¹9’39” N, 7354’41” W, 27 Jun 1996, Aldana J. IMCN 4196, 1 C\&S, 6, 30590.08 - 210.3 mm SL, Colombia, Bolivar, Magdalena River Basin, Magdalena River in Hatillo de la Loba, 306 Oct 2006, Ardila C. IMCN 8232, 3, 153.8 - 180.4 mm SL, Colombia, Tolima, Magdalena River in Honda, 307 ca. $5^{\circ} 14^{\prime} 05^{\prime \prime} \mathrm{N}, 7^{\circ} 43^{\prime} 43^{\prime \prime} \mathrm{W}, 12$ Jan 2007, Ortega-Lara A. IMCN 8233, 6, 99.4 - 275.0 mm SL, Colombia, 308 Córdoba, San Jorge River in La Balsa, Corregimiento La Apartada, ca. 801'40” N, 75²3’04” W, 20 Jan 309 2016, Vallecilla-Valencia V., Ortega-Lara A. IMCN 8237, 7, 202 - 225 mm SL, Colombia, Santander, 310 Magdalena River Basin, Magdalena River in Barrancabermeja, 701'56” N, 7352’35” W, 26 Sep 2011, 311 Ortega-Lara A. IMCN 8238, 1, 62.6 mm SL, Colombia, Bolívar, Magdalena River Basin, Yanacue stream 312 in the Yanacue town, $7^{\circ} 18^{\prime} 14^{\prime \prime} \mathrm{N}, 7^{\circ} 01^{\prime} 16^{\prime \prime} \mathrm{W}, 15$ Aug 2010, Ortega-Lara A. IMCN 8266, 1 DS, 203.5 313 mm SL, Colombia, Antioquia, Magdalena River Basin, Cauca River in Barrio Chino, Caucasia, 80’35.3” 314 N, 750’0” W, Dec 2015, Restrepo-Gómez A.M. IMCN 8268, 1 DS, 160 mm SL, Colombia, Bolívar, 315 Magdalena River Basin, Cauca River in San Jacinto del Cauca, 8¹2’7.5” N, 7445’15.5” W, Dec 2015, 316 Restrepo-Gómez A.M. IMCN 8271, 1, 198.6 mm SL, Colombia, Bolívar, Magdalena River Basin, Cauca 317 River in Punta Cartagena, Pinillos, 853’37.4” N, 74²8'28.5” W, Apr 2015, Olaya G.

\section{Non-type material.}

320 CIUA 366, 95 mm SL, Colombia, Cesar, Magdalena River Basin, Tucuy River in Becerril, 941’35” N, 321 73²7’42.1” W, May 2006, Montoya A.F. CIUA 367, 120 mm SL, Colombia, Cesar, Magdalena River 
322 Basin, Maracas River in Becerril, 944’46.2” N, 73¹0’38” W, May 2006, Montoya A.F. CIUA 528 3, 210

$323-245$ mm SL, Colombia, Valle del Cauca, Cauca River Basin, in Río Frío, 407’52.4” N, 76¹6’22.1” W,

324 Jan 2007, Ochoa L., Ospina J.G. CIUA 840, 8 DS, Colombia, Antioquia, Magdalena River Basin, 325 Magdalena River in Puerto Berrío, 6³0’27.8” N, 74²3’49.3” W, Aug 2006, Cano J.M. CIUA 841, 7 DS, 326 Colombia, Antioquia, Magdalena River Basin, Magdalena River in Puerto Berrío, 6³0’27.8” N, 327 74²3’49.2” W, Aug 2006, Cano J.M. CIUA 1151, 4, 135 - 160 mm SL, Colombia, Antioquia, Magdalena 328 River Basin, Magdalena River in Puerto Berrío, 6³0’27.8” N, 74²3’49.3” W, Aug 2009, Jiménez L.F. 329 CIUA 2029, 2, 81.2 - 82.1 mm SL, Colombia, Santander, Magdalena River Basin, Sogamoso River in 330 Betulia, 705'14.2” N, 73²3’52” W, Jan 2011, Pelayo P. CIUA 2987, 195 mm SL, Colombia, Santander, 331 Magdalena River Basin in El Llanito floodplain lake, 7¹0’12.2” N, 7351’43.8” W, Aug 2010, Carvajal 332 J.D., Hernández A. CIUA 3240, 250, 200 mm SL, Colombia, Antioquia, Magdalena River Basin, 333 Magdalena River in Puerto Berrío, 6³0’27.8” N, 74²3’49.3” W, Jun 2013, Jiménez L.F. CIUA 3291, 2 , 334145 - 190 mm SL, Colombia, Antioquia, Magdalena River Basin, Magdalena River in Puerto Berrío, 335 6³0’27.8” N, 74²3’49.2” W, Jun 2013, Jiménez L.F. CIUA 3668, 190 mm SL, Colombia, Antioquia, 336 Magdalena River Basin, Magdalena River in Puerto Berrío, 6²9’50” N, 74²3’53” W, Aug 2014, Jiménez 337 L.F. CIUA 4797, 190 mm SL, Colombia, Antioquia, Magdalena River Basin, Magdalena River in Puerto 338 Berrío, 6²9’50” N, 74²3’53” W, May 2015, Londoño J.

340 Diagnosis. Pseudopimelodus atricaudus (Fig. 9) differs from the other Pseudopimelodus species by

341 having a dark band covering $3 / 4$ of the caudal fin with base of rays and tip of caudal-fin lobes hyaline (vs.

342 narrow vertical dark band along the center of caudal fin in P. bufonius, P. magnus, and P. schultzi,

343 although in some specimens is hardly visible; base of rays hyaline and broad band covering $\leq 1 / 2$ caudal

344 fin in P. charus and P. mangurus), anterior margin of the dorsal-fin spine smooth (vs. serrated; Fig. 10).

345 Pseudopimelodus atricaudus differs from other Pseudopimelodus species except $P$. mangurus by having a 346 total of 39 vertebrae (vs. 38 in P. bufonius; $43-44$ in P. magnus, Fig. 3; 41 in P. schultzi). It differs from

347 P. magnus by having a shallowly concave lateral margin of the transverse process of the fourth vertebra 
348 of the Weberian complex (Fig. 4 vs. deeply acute notch). Junction of the posterior margin of the

349 transverse process of the fourth vertebra at angle approaching $90^{\circ}\left(v s .<90^{\circ}\right.$; Figs. 4 and 5). It differs

350 from $P$. magnus, $P$. bufonius, and $P$. mangurus by having a longer Weberian complex in relation to the

351 length of the neurocranium (46.9 - 55.5\%, Fig. 5 vs. $32.1-36.3 \%$ in P. magnus, $33.5 \%$ in P. bufonius,

352 and $42.7 \%$ in P. mangurus). It differs from P. bufonius and P. mangurus by having shorter maxillary

353 barbels, not surpassing the opercular margin (vs. surpassing). It differs from other Pseudopimelodus

354 species except $P$. magnus by the length of the posterior process of cleithrum $(1.25-1.62$ times the width

355 of the pectoral-fin spine base vs. $0.57-0.75$ in P. bufonius, $2.22-2.76$ in P. schultzi, $2.24-2.30$ in $P$.

356 mangurus). It differs from other Pseudopimelodus species except $P$. magnus and $P$. schultzi by having a

357 heart-shaped gas bladder (vs. dumbbell-shaped; Fig. 6).

358

359 Description. Morphometric data in Table 3. Body depressed from snout to dorsal-fin origin; progressively

360 compressed towards caudal-fin base. Snout rounded in dorsal view. Head as long as wide and covered by

361 thick skin hiding fontanel and cranial roof bones. Eye small, covered by skin and positioned latero-dorsally.

362 Prognathous jaw. Teeth small and villiform. Premaxilla laterally projected backwards, surpassing lateral

363 process of lateral ethmoid. Anterior nostril tubular, located lateroposteriorly to maxillary barbel base (Figs.

3648 and 10). Distance from anterior nostril to eye greater than distance to posterior nostril. Maxillary barbel

365 reaching opercular margin. Mental barbel inserted anterior to gular apex. Inner mental barbel surpassing

366 gular apex. Outer mental barbel surpassing branchial opening. Gular fold V-shaped, with rounded apex

367 (Fig. 8). Branchiostegal membrane free from isthmus. Posterior process of cleithrum triangular, 1.25 - 1.62

368 of width of pectoral-fin spine base.

369 Vomer T-shaped, with bifurcated posterior process (Fig. 4b) and in contact with parasphenoid, mesethmoid,

370 and lateral ethmoid. Posterior region of mesethmoid wider than base of parieto-supraoccipital process.

371 Lateral margin of transverse process of fourth vertebra of Weberian complex smoothly-concave joining

372 posteriorly to vertebral centra at right angle. Length of Weberian complex in relation to length of

373 neurocranium $32.2-36.3 \%$. Anterior fontanel elongated, reaching a transverse line through anterolateral

Peer] reviewing PDF | (2018:07:29459:3:0:NEW 18 Jul 2020) 
374 process of lateral ethmoid (Fig. 5b). Posterior fontanel small and oval-shaped, located at center of parieto375 supraoccipital (Fig. 5b). Parieto-supraoccipital process rectangular, slightly wider at base, with bifurcated 376 tip in contact with supraneural (Fig. 5b). Heart-shaped gas bladder (Fig. 6). Lateral line complete, reaching 377 caudal-fin base. Total number of vertebrae 39. Dorsal-fin origin at anterior third of body, posterior margin 378 straight, dorsal-fin spine strongly ossified, of equal length to first branched ray. Anterior margin of dorsal379 fin spine smooth with its distal end pointed. Dorsal-fin rays I, 6. Adipose-fin origin at level of anal fin 380 origin. Pectoral-fin spine with serrations and covered by skin, anterior and posterior margins with $17-19$ 381 and $13-17$ serrations, respectively. Serrations on posterior margin slightly larger than those on anterior 382 margin. Posterior edge of pectoral fin straight. Axillary pore present. Pectoral-fin rays I, 7. Pelvic fin emarginated, inserted behind end of dorsal-fin base. Pelvic-fin rays i, 5. Anal fin with rounded posterior edge and inserted below 17 th vertebra. Anal-fin rays v, 7. Caudal-fin bifurcated, with pointed lobes, upper lobe slightly narrower and longer than ventral lobe. Caudal-fin rays i, 8, 7, i; dorsal procurrent rays 17; ventral procurrent rays 17 .

387

388

Color in life and alcohol. Body covered by yellowish mucus with four irregularly-shaped dark bands on

389

390

391

392

393 394 395

396 397 pre-dorsal, subdorsal, sub-adipose region, and caudal-fin base, clearly visible in juveniles (Fig. 11), but faint in adult specimens. Pre-dorsal and subdorsal bands not joined. Remaining bands variably joined at different levels without defined pattern. Body with small dark and scattered spots and belly whitish. Dorsal and anal fins brown with posterior margin pale. Caudal-fin base hyaline, dark brown on its posterior three-quarters. Pectoral and pelvic fins reddish with dark band at base. Color in alcohol similar to color in life.

Distribution. It is found on the Magdalena River below $200 \mathrm{~m}$ asl from the confluence of the Guali River in the city of Honda and in the middle and lower basins of the Cauca River, close to the mouth (Fig. 8).

Etymology. The specific name atricaudus is from the Latin, "ater" (black) and "cauda" (tail) and refers to the diagnostic black caudal fin.

Peer] reviewing PDF | (2018:07:29459:3:0:NEW 18 Jul 2020) 
401 Discussion

402 Molecular and morphological approaches were used in this study to test the hypothesis that undescribed

403 species of Pseudopimelodus occur in Colombia. Available COI sequences allowed phylogenetic

404 comparisons of samples studied here with members of all Pseudopimelodus species and other genera of

405 Pseudopimelodidae. In contrast to the remaining Pseudopimelodus species, some osteological features

406 remained unaddressed in $P$. charus, due to the lack of skelotonized specimens, although we could analyze

407 its external morphology and coloration patterns.

408 This study provides evidence of two new species of Pseudopimelodus from the Magdalena-Cauca River

409 Basin, which due to similarities in the external morphology and lack of adequate taxonomic studies, were

410 formerly identified as P. bufonius or P. schultzi (see synonymy of new species). Pseudopimelodus

411 magnus shows a well-supported sister group relationship with $P$. schultzi, whereas $P$. atricaudus is the

412 sister group to all Pseudopimelodus species. Additionally, the genetic distances in Pseudopimelodus

413 species (see section molecular analyses) are concordant with intraspecific variation reported in

414 Siluriformes (Hubert et al., 2008), except for P. bufonius from the Orinoco River Basin that showed larger

415 genetic distances from its conspecifics from the Vaupés and Orteguaza rivers. A recent study indicates

416 that $P$. atricaudus (lineage 1) diverged from P. magnus (lineage 5) about 16 mya, resulting from the uplift

417 of the Antioqueño Plateau (Rangel-Medrano, Ortega-Lara \& Márquez, 2020).

418 The new Pseudopimelodus species present three synapomorphies (thick skin on pectoral-fin spine, tip of

419 pectoral-fin spine bifurcated and, small pseudotympanum opening) for the clade [Cruciglanis,

420 Pseudopimelodus] Rhyacoglanis] and two synapomorphies for Pseudopimelodus (triangular

421 mesacoracoid and a short posterior cleithral process) previously reported by Shibatta \& Vari (2017).

422 Additionally, juveniles of $P$. atricaudus shows clearly visible bands while adult specimens exhibit faint or

423 no bands with small dark and scattered spots, supporting one of the synapomorphies of

424 Pseudopimelodidae.

Peer] reviewing PDF | (2018:07:29459:3:0:NEW 18 Jul 2020) 
425 However, the findings of heart-haped gas bladder in the two new species described herein, P. mangurus, 426 and P. schultzi, do not provide support to the dumbbell-shaped gas bladder (Birindelli, Shibatta, 2011) as 427 synapomorphy of the clade [Cruciglanis, Pseudopimelodus] Rhyacoglanis] (Shibatta \& Vari, 2017).

428 Compared with Shibatta \& Vari (2017), this study also found a wider range of number of vertebrae (38 $42944 v s .41-42$ ), partial fusion between predorsal and subdorsal bands (vs. absent), and short maxillary 430 barbels, falling short of vertical through dorsal-fin origin, although they are shorter in $P$. magnus and do 431 not reach the opercular margin in P. atricaudus.

432 Moreover, the anteriorly smooth dorsal-fin spine in P. atricaudus contrasts with the anteriorly serrated 433 dorsal-fin spine described in Pseudopimelodus and Rhyacoglanis (Shibatta \& Vari, 2017). This character, 434 along with the pigmentation pattern of the caudal fin, represent autapomorphies for P. atricaudus. The 435 largest body size and the highest number of vertebrae allow the discrimination of $P$. magnus from 436 congeners, including P. mangurus, the longest Pseudopimelodus species known until now (see Shibatta, 437 2003). Likewise, the angles formed, in ventral view, between anterior and lateral margins of transverse 438 process of the fourth vertebra of the Weberian complex also provided a diagnostic trait for P. magnus. 439 Pseudopimelodus now includes six species (P. atricaudus, P. bufonius, P. charus, P. magnus, P. 440 mangurus, $P$. schultzi), although this number is expected to increase, given the high genetic divergence 441 observed among its members (Rangel-Medrano, Ortega-Lara \& Márquez, 2020). The high genetic 442 divergence observed among specimens from the Sinú River (type locality of $P$. schultzi) and other Pseudopimelodus, suggests that $P$. schultzi is restricted to only the Caribbean river basin and therefore its 444 presence in the Magdalena-Cauca River Basin must be questioned. These results contribute to redefine 445 the geographical distribution of Pseudopimelodus in northwestern South America and may support 446 further studies in phylogenetics, fisheries, reproduction, and population genetics to eventually elucidate 447 the basic biology of these species and their conservation status.

448

\section{Conclusions}


450 Based on molecular and morphological analyses, this study describes two new species of

451 Pseudopimelodus Bleeker, 1858 (Siluriformes: Pseudopimelodidae) from the Magdalena-Cauca River

452 Basin, Colombia. These results show the taxonomical complexity of Pseudopimelodus in an area where

453 the presence of only two of four members of this genus have been recorded. Thus, further taxonomic as

454 well as phylogenetic studies of Pseudopimelodus are needed to clarify the status of divergent lineages

455 currently included in this genus.

456

457 Acknowledgments

458 Authors thank Fundación para la Investigación y el Desarrollo Sostenible (FUNINDES) for logistical

459 support and facilities, IMCN, INCIVA, for allowing examination of specimens from the reference

460 collection at their facilities. To Darlyn Fabiola Mosquera, Carlos Ardila-Rodríguez, Viki Vallecilla and

461 Libardo Tapiero, for collection of part of the studied material. To Raúl Ríos (IMCN), Luz Fernanda

462 Jiménez (GUIA), Francisco Villa-Navarro (CZUT-P), Iván Mojica (ICN-MHN), Carlos Ardila-Rodríguez

463 (CAR), Tulia Rivas (UTCH-P), and Jonathan Armbruster (AUM), for the loan of specimens and logistical

464 support while visiting collections. Authors also thank Anderson Cardona Ruiz, Giovany Olaya Betancur

465 and Mauricio Urrego Tobón for their assistance with photographs. Donald Taphorn and the anonymous

466 reviewers for their comments, which improved the final version of this article.

467

468 References

469 Arratia G. 2003a. Catfish head skeleton - an overview. In: Arratia G, Kapoor BG, Chardon M, Diogo R, $470 \quad$ editors. Catfishes. Enfield: Science Publishers, Inc. p.3 - 46.

471 Arratia G. 2003b. The Siluriform postcranial skeleton - an overview. In: Arratia G, Kapoor BG, Chardon

472 M, Diogo R, editors. Catfishes. Enfield: Science Publishers, Inc. p.121 - 157.

473 Birindelli JLO, Shibatta OA. 2011. Morphology of the gas bladder in bumblebee catfishes (Siluriformes,

474 Pseudopimelodidae). Journal of Morphology 272(7):890 - 96 DOI 10.1002/jmor.1096. 
475 Dahl G. 1971. Los peces del norte de Colombia. Ministerio de Agricultura, Instituto de Desarrollo de los

476

477

478

479

480

481

482

483

484

485

486

487

488

489

490

491

492

493

494

495

496

497

498

499

500

Recursos Naturales Renovables (INDERENA). Talleres Litografía Arco. Bogotá D.C., Colombia. $391 \mathrm{p}$.

de Carvalho DC, Oliveira DAA, Pompeu PS, Gontijo-Leal C, Oliveira CO, Hanner R. 2011. Deep barcode divergence in Brazilian freshwater fishes: the case of the São Francisco River Basin. Mitochondrial DNA 22:sup1, 80 - 86 DOI 10.3109/19401736.2011.588214

Diogo RM, Chardon M, Vandewalle P. 2004. Osteology and myology of the cephalic region and pectoral girdle of Batrochoglanis raninus, with a discussion on the synapomorphies and phylogenetic relationships of the Pseudopimelodinae and Pimelodidae (Teleostei: Siluriformes). Animal Biology 54(3): 261 - 280 DOI 10.1163/1570756042484728.

DoNascimiento C, Herrera-Collazos EE, Herrera GA, Ortega-Lara A, Villa-Navarro FA, Usma Oviedo JS, Maldonado Ocampo JA. 2017. Checklist of the freshwater fishes of Colombia: a Darwin Core alternative to the updating problem. Zookeys 708:25 - 138 DOI 10.3897/zookeys.708.13897.

Eigenmann CH, Eigenmann RS. 1890. A revision of the South American Nematognathi or cat-fishes. Occasional Papers of the California Academy of Sciences 1: 1-508.

Eigenmann CH. 1922. The fishes of Western South America. Part 1. The freshwater fishes of Northwestern South America. Including Colombia, Panamá, and the pacific slopes of Ecuador and Perú, together with and appendix upon the fishes of the Rio Meta in Colombia. Memoirs of the Carnegie Museum 9 (1): 1 - 346.

Ferraris CJ, Jr. 2007. Checklist of catfishes, recent and fossil (Osteichthyes: Siluriformes), and catalogue of Siluriformes primary types. Zootaxa 1418:1 - 628 DOI 10.11646/zootaxa.1418.1.1.

Fricke R, Eschmeyer WN, Fong JD. 2020. Species by family/subfamily. Available at: http://researcharchive.calacademy.org/research/ichthyology/catalog/SpeciesByFamily.asp. Electronic version accessed 08-04-2020.

Hardman M. 2005. The phylogenetic relationships among non-Diplomystid catfishes as inferred from mitochondrial cytochrome b sequences; the search for the ictalurid sister taxon (Otophysi: 
501

502

503

504

505

506

507

508

509

510

511

512

513

514

515

516

517

518

519

520

521

522

523

524

525

526

Siluriformes). Molecular Phylogenetics and Evolution 37:700 - 720 DOI

10.1016/j.ympev.2005.04.029.

Hubert N, Hanner R, Holm E, Mandrak NE, Taylor E, Burridge M, Watkinson D, Dumont P, Curry A, Bentzen P, Zhang J, April J, Bernatchez L. 2008. Identifying Canadian freshwater fishes through DNA barcodes. PLoS One 3(6): e2490 DOI 10.1371/journal.pone.0002490.

Jiménez-Segura LF, Ortega-Lara A. Pseudopimelodus cf. bufonius (Valenciennes 1840). Chapter 7. Pp. 544 - 546. in: Lasso CA, Agudelo Córdoba E, Jiménez-Segura LF, Ramírez-Gil H, MoralesBetancourt M, Ajiaco-Martínez RE, de Paula Gutiérrez F, Usma Oviedo JS, Muñoz Torres SE, Sanabria Ochoa AI (Eds). 2011. I. Catálogo de los recursos pesqueros continentales de Colombia. Serie Editorial Recursos Hidrobiológicos y Pesqueros Continentales de Colombia. Instituto de Investigación de los Recursos Biológicos Alexander von Humboldt (IAvH). Bogotá, D.C., Colombia, 715p.

Kalyaanamoorthy S, Minh BQ, Wong TKF, Von Haeseler A, Jermiin LS. 2017. ModelFinder: Fast model selection for accurate phylogenetic estimates. Nature Methods 14:587 - 589 DOI 10.1038/nmeth.4285.

Lundberg JG, Bornbusch AH, Mago-Leccia F. 1991. Gladioglanis conquistador n. sp. from Ecuador, with diagnoses of the subfamilies Rhamdiinae Bleeker and Pseudopimelodinae n. subf. (Siluriformes: Pimelodidae). Copeia 1991(1):190 - 209 DOI 10.2307/1446263.

Lundberg JG, Sullivan JP, Hardman M. 2011. Phylogenetics of the South American catfish family Pimelodidae (Teleostei: Siluriformes) using nuclear and mitochondrial gene sequences. Proceedings of the Academy of Natural Sciences of Philadelphia 161:153 - 189 DOI 10.1635/053.161.0110.

Maldonado-Ocampo JA, Ortega-Lara A, Usma OJS, Galvis VG, Villa-Navarro FA, Vásquez GL, PradaPedreros S, Ardila RC. 2005. Peces de los Andes de Colombia. Instituto de Investigación de Recursos Biológicos Alexander Von Humboldt. Bogotá, D.C. - Colombia. 346 p DOI 10.1590/S1679-62252006000300011.

Peer] reviewing PDF | (2018:07:29459:3:0:NEW 18 Jul 2020) 
527 Mees GF. 1974. The Auchenipteridae and Pimelodidae of Suriname (Pisces, Nematognathi). Zoologische $528 \quad$ Verhandelingen. Leiden. 132:1-256, Pls. 1-15.

529 Miles C. 1947. Los peces del río Magdalena (A Field Book of Magdalena Fishes). Doctoral Thesis 530 dissertation. Facultad de Filosofía y Letras, Pontificia Universidad Católica Javeriana. Bogotá, 531 D.C., Colombia. 214p.

532 Mojica JI, Galvis G, Arbeláez F, Sánchez-Duarte P, Castellanos C, Villa-Navarro FA. 2006. Peces del 533 valle medio del Río Magdalena, Colombia. Biota Colombiana 7:23 - 38 .

534 Ortega-Lara A, Lehmann P. 2006. Cruciglanis, a new genus of Pseudopimelodid catfish (Ostariophysi: 535 Siluriformes) with description of a new species from the Colombian Pacific coast. Neotropical 536 Ichthyology 4:147 - 156 DOI 10.1590/S1679-62252006000200002.

537 Ortega-Lara A, Usma JS, Bonilla PA, Santos NL. 2006. Peces de la cuenca alta del río Cauca, Colombia. 538 Biota Colombiana 7:39 - 54 DOI:10.21068/bc.v7i1.164.

539

540

541

542

543

544

545

546

547

548

549

550

551

Ortega-Lara A, Rivas TS, Rincón CE. Pseudopimelodus schultzi (Dahl 1955). Chapter 7. Pp. 547 - 550. In: Lasso CA, Agudelo Córdoba E, Jiménez-Segura LF, Ramírez-Gil H, Morales-Betancourt M, Ajiaco-Martínez RE, de Paula Gutiérrez F, Usma Oviedo JS, Muñoz Torres SE, Sanabria Ochoa AI. (Eds). 2011. I. Catálogo de los recursos pesqueros continentales de Colombia. Serie Editorial Recursos Hidrobiológicos y Pesqueros Continentales de Colombia. Instituto de Investigación de los Recursos Biológicos Alexander von Humboldt (IAvH). Bogotá, D.C., Colombia, 715p.

Rambaut A. 2014. FigTree Version 1.4.2. Available at http://tree.bio.ed.ac.uk/software/figtree/

Rangel-Medrano JD, Ortega-Lara A, Márquez EJ. 2020. Ancient genetic divergence in bumblebee catfish of the genus Pseudopimelodus (Pseudopimelodidae: Siluriformes) from northwestern South America. PeerJ 8:e9028 DOI 10.7717/peerj.9028.

Ronquist F, Teslenko M, Van Der Mark P, Ayres DL, Darling A, Hohna S, Larget B, Liu L, Suchard MA, Huelsenbeck JP. 2012. Mrbayes 3.2: Efficient Bayesian phylogenetic inference and model choice across a large model space. Systematic Biology 61:539 - 542 DOI 10.1093/sysbio/sys029. 
552 Sabaj M.H. 2019. Standard symbolic codes for institutional resource collections in herpetology

553

554

555

556

557

558

559

560

561

562

563

564

565

566

567

568

569

570

571

572

573

574

575 and ichthyology: An Online Reference. Version 7.1 (21 March 2019). Electronically accessible at http://www.asih.org. American Society of Ichthyologists and Herpetologists, Washington, DC.

Shibatta OA. 2003. Family Pseudopimelodidae (Bumblebee catfishes, dwarf marbled catfishes). Pp. 401 405. In: Reis, R. E., S. O. Kullander \& C. J. Ferraris, Jr. (Eds.). Check List of the Freshwater Fishes of South and Central America. Porto Alegre, Edipucrs, 729p DOI 10.1643/OT-04-142.

Shibatta OA. 2016. A new species of bumblebee catfish of the genus Microglanis (Siluriformes: Pseudopimelodidae) from the Upper Rio Paraguay Basin, Brazil. Neotropical Ichthyology 14:1 7 DOI 10.1590/1982-0224-20160031.

Shibatta OA, Vari RP. 2017. A new genus of Neotropical rheophilic catfishes, with four new species (Teleostei: Siluriformes: Pseudopimelodidae). Neotropical Ichthyology 15(2), 1 - 30 DOI 10.1590/1982-0224-20160132.

Shibatta OA. 2019. New species of bumblebee catfish of the genus Batrochoglanis Gill, 1858 (Siluriformes: Pseudopimelodidae) from the Aripuanã River basin, Mato Grosso, Brazil. Zootaxa 4674(2):243 - 263 DOI 10.11646/zootaxa.4674.2.6.

Steindachner F. 1880. Zur Fisch-fauna des Cauca und der Flüsse bei Guayaquil. Denkschriften der Mathematisch-Naturwissenschaftlichen Classe der Kaiserlichen Akademie der Wissenschaften in Wien 42, 55 - 104, Pp. 1 - 9.

Sullivan JP, Lundberg JG, Hardman M. 2006. A phylogenetic analysis of the major groups of catfishes (Teleostei: Siluriformes) using rag1 and rag2 nuclear gene sequences. Molecular Phylogenetics and Evolution 41:636 - 662 DOI 10.1016/j.ympev.2006.05.044.

Sullivan JP, Muriel-Cunha J, Lundberg JG. 2013. Phylogenetic relationships and molecular dating of the major groups of catfishes of the Neotropical superfamily Pimelodoidea (Teleostei: Siluriformes). 
$576 \quad$ Proceedings of the Academy of Natural Sciences of Philadelphia 162:89 - 110 DOI

$577 \quad 10.1635 / 053.162 .0106$.

578 Tamura K, Stecher G, Peterson D, Filipski A, Kumar S. 2013. MEGA6: molecular evolutionary genetics 579 analysis version 6.0. Molecular Biology and Evolution 30(12):2725 - 9 DOI

$580 \quad 10.1093 / \mathrm{molbev} / \mathrm{mst} 197$.

581 Taylor WR, Van Dyke GC. 1985. Revised procedures for staining and clearing small fishes and other $582 \quad$ vertebrates for bone and cartilage study. Cybium 9:107-119.

583 Tobes I, Falconí-López A, Valdiviezo-Rivera J, Provenzano-Rizzi F. 2020. A new species of Microglanis 584 (Siluriformes: Pseudopimelodidae) from the Pacific slope of Ecuador. Neotropical Ichthyology $58518(2): 1-19$ DOI 10.1590/1982-0224-2019-0023.

586 Villa-Navarro FA, Zúñiga-Upegui PT, Castro-Roa D, García-Melo JE, García-Melo LJ, Herreda-Yara 587 ME. 2006. Peces del alto Magdalena, cuenca del río Magdalena, Colombia. Biota Colombiana 7:

588 $3-22$ DOI 10.21068/bc.v7i1.162.

589

Wilcox TP, Zwickl DJ, Heath TA, Hillis DM. 2002. Phylogenetic relationships of the dwarf boas and a 590 comparison of Bayesian and bootstrap measures of phylogenetic support. Molecular Phylogenetic

591 and Evolution 25:361 - 371 DOI 10.1016/S1055-7903(02)00244-0.

592 


\section{Table $\mathbf{1}$ (on next page)}

List of $\mathrm{COI}$ sequences of species of Pimelodoidea used for phylogenetic analysis.

${ }^{1}$ Rangel-Medrano, Ortega-Lara \& Márquez (2020); ${ }^{2}$ Oliveira, pers comm; ${ }^{3}$ de Carvalho et al., 2011. 


\begin{tabular}{|c|c|c|c|}
\hline Species & Geography & GenBank accession & Sample size \\
\hline Pseudopimelodus atricaudus $\mathrm{H}^{1}$ & Cauca River lower sector & MH553571 & 1 \\
\hline Pseudopimelodus atricaudus $\mathrm{H} 8^{1}$ & Cauca River lower sector & MH553578, MH800618- MH800636 & 20 \\
\hline Pseudopimelodus atricaudus $\mathrm{H} 11^{1}$ & Cauca River lower sector & MH553581 & 1 \\
\hline Pseudopimelodus atricaudus $\mathrm{H} 21^{1}$ & Magdalena River lower sector & MH553591 & 1 \\
\hline Pseudopimelodus magnus $\mathrm{H} 12^{1}$ & Cauca River middle sector & MH553582 & 1 \\
\hline Pseudopimelodus magnus $\mathrm{H} 13^{1}$ & Cauca River middle sector & MH553583 & 1 \\
\hline Pseudopimelodus magnus $\mathrm{H} 14^{1}$ & Cauca River middle sector & MH553584 & 1 \\
\hline Pseudopimelodus magnus $\mathrm{H}_{1} 6^{1}$ & Cauca River middle sector & MH553586 & 1 \\
\hline Pseudopimelodus magnus $\mathrm{H} 17^{1}$ & Magdalena River upper sector & MH553587, MH800728- MH800730 & 4 \\
\hline Pseudopimelodus magnus $\mathrm{H} 18^{1}$ & Cauca River middle sector & MH553588, MH800711- MH800714 & 5 \\
\hline Pseudopimelodus magnus $\mathrm{H} 19^{1}$ & Cauca River middle sector & MH553589 & 1 \\
\hline Pseudopimelodus magnus $\mathrm{H} 20^{1}$ & Cauca River middle sector & MH553590 & 1 \\
\hline Pseudopimelodus magnus $\mathrm{H} 23^{1}$ & Cauca River upper sector & MH553593 & 1 \\
\hline Pseudopimelodus magnus $\mathrm{H} 24^{1}$ & Cauca River upper sector & MH553594 & 1 \\
\hline Pseudopimelodus schultzi $\mathrm{H} 25^{1}$ & Sinú River & MH553595 & 1 \\
\hline Pseudopimelodus schultzi $\mathrm{H} 26^{1}$ & Sinú River & MH553596 & 1 \\
\hline Pseudopimelodus bufonius $\mathrm{H} 27^{1}$ & Vaupés River & MH800834 & 1 \\
\hline Pseudopimelodus bufonius $\mathrm{H} 28^{1}$ & Orteguaza River & MH553598, MH800832 & 2 \\
\hline Pseudopimelodus bufonius $\mathrm{H}_{3} 3^{1}$ & Orinoco River & MH553603 & 1 \\
\hline Pseudopimelodus mangurus ${ }^{2}$ & Paranapanema River & EU179816 & 1 \\
\hline Pseudopimelodus charus ${ }^{2}$ & São Francisco River & EU179815 & 1 \\
\hline Cruciglanis sp. AOL $81^{1}$ & Mira River & MH553609 & 1 \\
\hline Cruciglanis pacifici AOL094 ${ }^{1}$ & Anchicayá River & MH553607 & 1 \\
\hline Rhyachoglanis annulatus AOL097-98 ${ }^{1}$ & Meta River & MH553605-06 & 2 \\
\hline Rhyachoglanis pulcher ${ }^{2}$ & --- & EU179812 & 1 \\
\hline Cephalosilurus apurensis ${ }^{2}$ & Orinoco River & EU179818 & 1 \\
\hline Batrochoglanis raninus $^{2}$ & Aquarium & EU179809 & 1 \\
\hline Lophiosilurus alexandri ${ }^{3}$ & São Francisco River & HM405152 & 1 \\
\hline Microglanis sp. AOL $095^{1}$ & Acacias River & MH553604 & 1 \\
\hline Pimelodus yuma ${ }^{1}$ & Cauca River lower sector & MH553610 & 1 \\
\hline Pseudoplatystoma magdaleniatum $^{1}$ & Cauca River lower sector & MH553611 & 1 \\
\hline
\end{tabular}


Table 2 (on next page)

Morphometric data of Pseudopimelodus magnus (32 specimens). 


\begin{tabular}{|c|c|c|c|c|c|}
\hline & Holotype & Max & Min & Mean & SD \\
\hline Standard length $(\mathrm{mm})$ & 750 & 531.7 & 168 & 279.4 & 86 \\
\hline \multicolumn{6}{|l|}{ Percentages of standard length } \\
\hline Head length & 23.3 & 32.1 & 23.3 & 30.0 & 1.4 \\
\hline Pre-dorsal distance & 30.0 & 36.8 & 30.0 & 34.5 & 1.2 \\
\hline Pre-pectoral distance & 24.0 & 27.6 & 23.7 & 25.2 & 1.0 \\
\hline Pre-pelvic distance & 41.3 & 58.8 & 41.3 & 53.2 & 2.9 \\
\hline Distance between pectoral-fin origin and dorsal-fin origin & 21.3 & 25.2 & 21.3 & 22.8 & 1.0 \\
\hline Distance between pectoral-fin origin and pelvic-fin origin & 22.0 & 35.7 & 22.0 & 31.4 & 2.5 \\
\hline Distance between dorsal-fin origin and pelvic-fin origin & 26.7 & 30.7 & 23.8 & 26.7 & 1.8 \\
\hline Dorsal-fin base length & 8.4 & 14.1 & 8.4 & 12.5 & 1.0 \\
\hline Distance between adipose-fin origin and pelvic-fin origin & 24.7 & 33.9 & 24.7 & 28.8 & 2.0 \\
\hline Distance between pelvic-fin origin and anal-fin origin & 19.7 & 27.9 & 19.7 & 25.4 & 1.6 \\
\hline Distance between anal-fin origin and adipose-fin origin & 19.3 & 19.3 & 13.1 & 15.7 & 1.4 \\
\hline Adipose-fin base length & 9.8 & 14.7 & 9.8 & 13.0 & 1.2 \\
\hline Anal-fin base length & 13.6 & 13.6 & 7.9 & 9.8 & 1.1 \\
\hline Pectoral-fin base length & 18.7 & 27.8 & 18.7 & 25.5 & 1.7 \\
\hline Pelvic-fin base length & 14.0 & 19.2 & 11.8 & 14.4 & 1.7 \\
\hline \multicolumn{6}{|l|}{ Percentages of head length } \\
\hline Orbital diameter & 5.6 & 9.1 & 4.6 & 6.0 & 1.1 \\
\hline Snout length & 41.7 & 41.7 & 24.5 & 33.6 & 2.8 \\
\hline Distance between maxillary barbels & 53.1 & 53.1 & 39.6 & 46.2 & 2.6 \\
\hline Distance between anterior most mesial point of snout and left anterior nostril & 11.6 & 18.8 & 9.3 & 14.0 & 2.6 \\
\hline Distance between maxillary barbel and eye & 14.0 & 19.1 & 13.3 & 15.8 & 1.3 \\
\hline Distance between anterior nostrils & 29.2 & 29.2 & 19.7 & 24.0 & 2.0 \\
\hline Distance between posterior nostrils & 34.5 & 34.5 & 23.0 & 27.2 & 2.3 \\
\hline Distance between anterior and posterior nostrils & 7.0 & 8.9 & 5.0 & 7.2 & 0.9 \\
\hline Distance between posterior nostril to eye & 9.0 & 9.0 & 4.4 & 7.1 & 1.0 \\
\hline Interorbital distance & 49.6 & 49.6 & 34.3 & 41.1 & 2.7 \\
\hline Mouth width & 73.2 & 82.7 & 60.1 & 71.9 & 5.9 \\
\hline Distance between outer mental barbels & 42.4 & 46.9 & 34.0 & 39.1 & 2.9 \\
\hline Distance between inner mental barbels & 23.3 & 24.5 & 16.3 & 21.0 & 2.2 \\
\hline
\end{tabular}




\section{Table 3(on next page)}

Morphometric data of Pseudopimelodus atricaudus (41 specimens). 


\begin{tabular}{|c|c|c|c|c|c|}
\hline & Holotype & Max & Min & Mean & SD \\
\hline Standard length $(\mathrm{mm})$ & 143.7 & 278.3 & 87.7 & 173 & 38.7 \\
\hline \multicolumn{6}{|l|}{ Percentages of standard length } \\
\hline Head length & 30.1 & 33.4 & 26.3 & 29.9 & 1.8 \\
\hline Pre-dorsal distance & 37.5 & 40.6 & 35.2 & 37.6 & 1.5 \\
\hline Pre-pectoral distance & 29.5 & 30.8 & 24.6 & 26.8 & 1.6 \\
\hline Pre-pelvic distance & 52.9 & 59.6 & 51.3 & 54.9 & 2.2 \\
\hline Distance between pectoral-fin origin and dorsal-fin origin & 23.9 & 27.4 & 21.6 & 24.7 & 1.2 \\
\hline Distance between pectoral-fin origin and pelvic-fin origin & 25.6 & 37.7 & 25.6 & 32.3 & 2.5 \\
\hline Distance between dorsal-fin origin and pelvic-fin origin & 25.7 & 30.5 & 21.6 & 26.5 & 2.1 \\
\hline Dorsal-fin base length & 14.8 & 16.9 & 13.1 & 14.8 & 0.8 \\
\hline Distance between adipose-fin origin and pelvic-fin origin & 24.8 & 36.8 & 24.1 & 29.1 & 2.4 \\
\hline Distance between pelvic-fin origin and anal-fin origin & 23.4 & 30.5 & 21.8 & 24.7 & 1.7 \\
\hline Distance between anal-fin origin and adipose-fin origin & 17.9 & 19.0 & 14.4 & 16.9 & 1.2 \\
\hline Adipose-fin base length & 17.8 & 17.8 & 11.9 & 15.1 & 1.6 \\
\hline Anal-fin base length & 11.7 & 13.3 & 9.5 & 10.8 & 0.9 \\
\hline Pectoral-fin base length & 23.7 & 32.1 & 20.4 & 25.5 & 3.1 \\
\hline Pelvic-fin base length & 17.2 & 23.3 & 13.4 & 17.6 & 2.2 \\
\hline \multicolumn{6}{|l|}{ Percentages of head length } \\
\hline Orbital diameter & 8.2 & 11.1 & 5.6 & 8.3 & 1.3 \\
\hline Snout length & 36.8 & 40.4 & 20.7 & 30.8 & 4.8 \\
\hline Distance between maxillary barbels & 45.3 & 56.5 & 42.2 & 48.9 & 3.3 \\
\hline Distance between anteriormost mesial point of snout and anterior nostril & 9.5 & 16.0 & 6.5 & 10.1 & 2.5 \\
\hline Distance between maxillary barbel and eye & 11.3 & 18.1 & 10.9 & 14.3 & 1.6 \\
\hline Distance between anterior nostrils & 26.9 & 30.5 & 20.9 & 25.8 & 2.3 \\
\hline Distance between posterior nostrils & 30.2 & 33.5 & 21.3 & 28.6 & 2.7 \\
\hline Distance between anterior and posterior nostrils & 7.1 & 9.4 & 4.2 & 7.0 & 1.0 \\
\hline Distance between posterior nostril to eye & 6.9 & 10.5 & 6.4 & 8.6 & 1.2 \\
\hline Interorbital distance & 43.0 & 49.4 & 34.5 & 43.2 & 3.9 \\
\hline Mouth width & 67.2 & 93.7 & 60.8 & 77.2 & 7.6 \\
\hline Distance between outer mental barbels & 47.8 & 51.2 & 38.6 & 44.4 & 2.9 \\
\hline Distance between inner mental barbels & 25.1 & 31.7 & 18.7 & 25.4 & 2.5 \\
\hline
\end{tabular}


Figure 1

Bayesian phylogenetic tree based on partial sequences of $\mathrm{COI}$ gene, showing the phylogenetic position of Pseudopimelodus magnus and $P$. atricaudus within Pseudopimelodidae. 


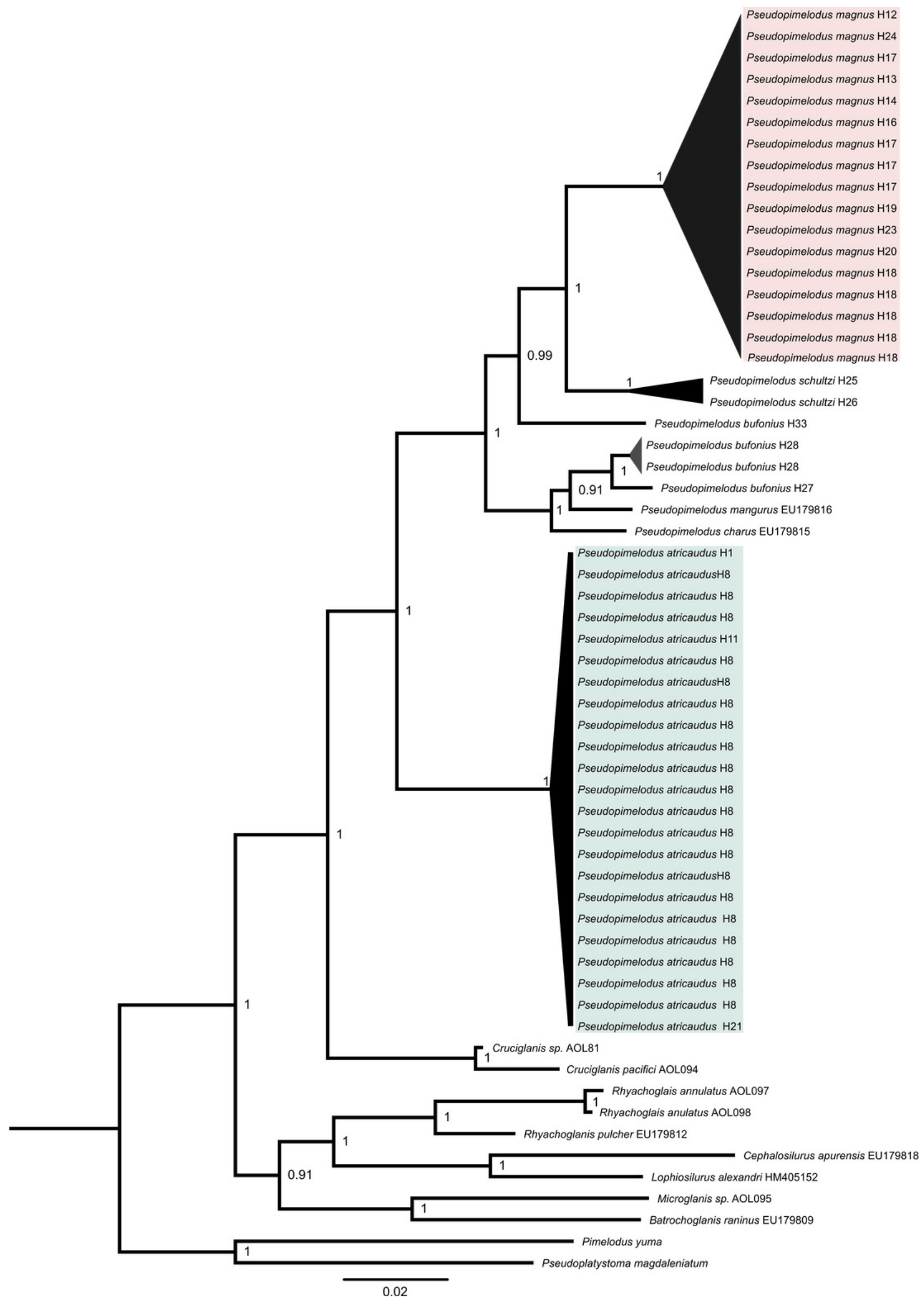


Figure 2

Pseudopimelodus magnus, holotype, CIUA 5142, 750 mm SL, Colombia, Antioquia, Magdalena River basin, Cauca River in Venecia.

a, b, c: dorsal, lateral, and ventral view, respectively. Scale bar $=5 \mathrm{~cm}$. Photography: Giovany Olaya Betancur. Photographic edition: Mauricio Urrego Tobón. 


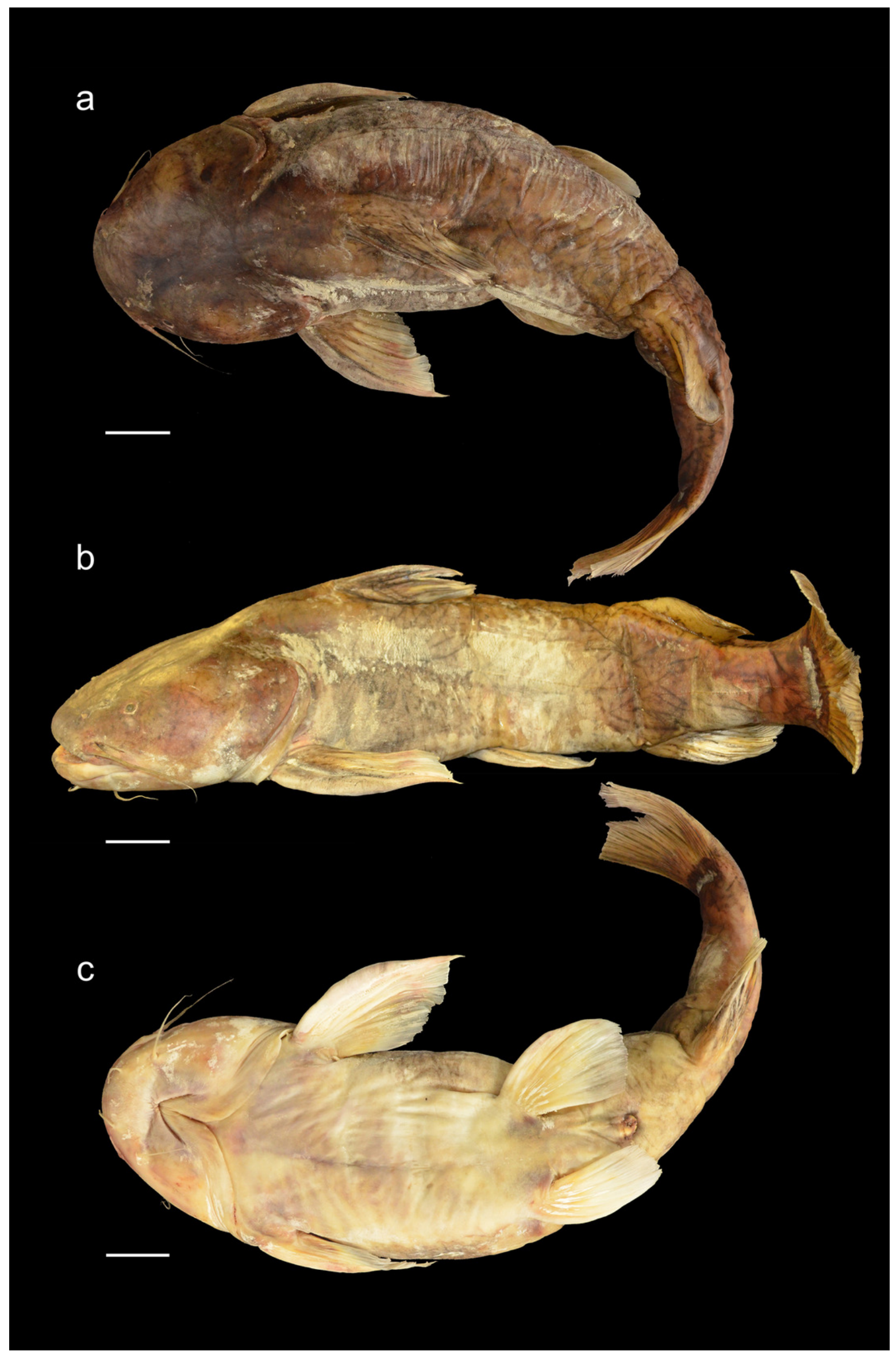

Peer) reviewing PDF | (2018:07:29459:3:0:NEW 18 Jul 2020) 


\section{Figure 3}

Dried skeletons of Pseudopimelodus magnus, paratype, IMCN 8265, $213.7 \mathrm{~mm} \mathrm{SL} \mathrm{(a)}$ and $P$. atricaudus, paratype, IMCN 8266, $203.5 \mathrm{~mm} \mathrm{SL}$ (b).

Scale bar $=1 \mathrm{~cm}$. Photography: Anderson Cardona Ruiz. Photographic edition: Mauricio Urrego Tobón.

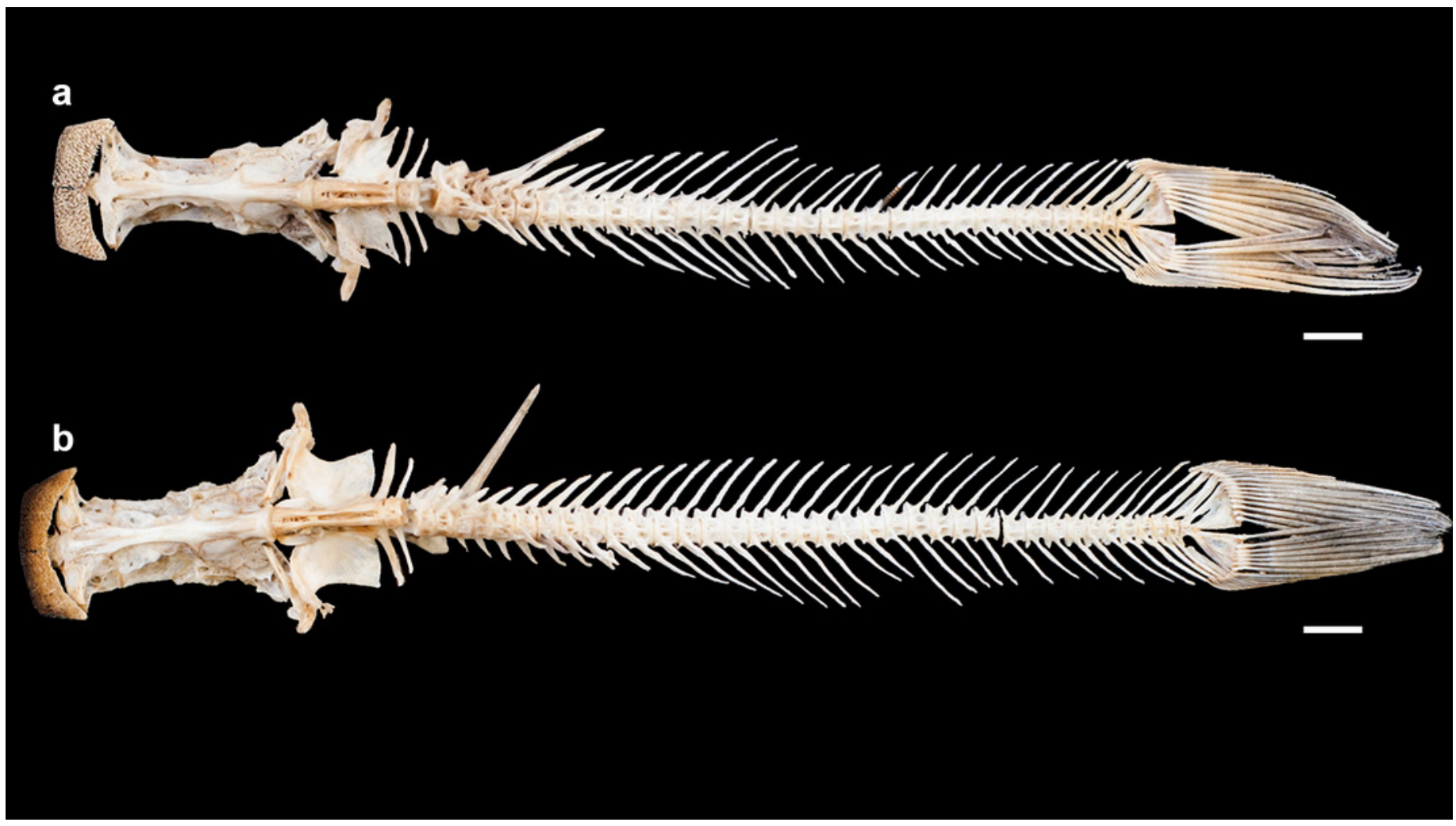




\section{Figure 4}

Neurocranium and Weberian complex in ventral view of Pseudopimelodus magnus, paratype, IMCN 8265, $213.7 \mathrm{~mm} \mathrm{SL}$ (a) and P. atricaudus, paratype, IMCN 8266, 203.5 $\mathrm{mm} \mathrm{SL}(\mathrm{b})$.

TP4: transverse process of fourth vertebra, TP5: transverse process of fifth vertebra. Scale bar: $1 \mathrm{~cm}$. Photography: Anderson Cardona Ruiz. Photographic edition: Mauricio Urrego Tobón.

*Note: Auto Gamma Correction was used for the image. This only affects the reviewing manuscript. See original source image if needed for review.

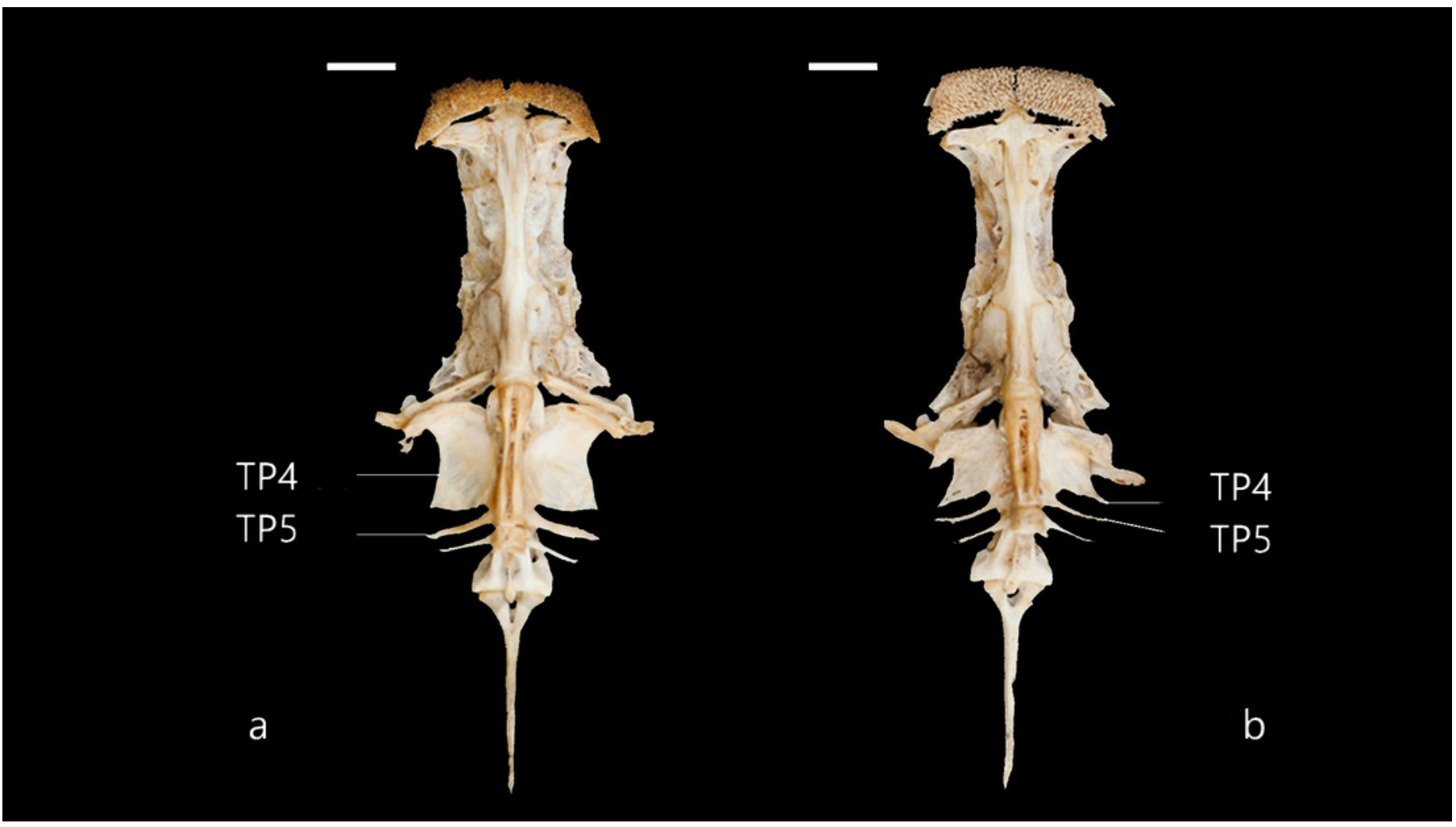




\section{Figure 5}

Neurocranium and Weberian complex in dorsal view of Pseudopimelodus magnus, paratype, IMCN 8265, 213.7 mm SL (a) and $P$. atricaudus, paratype, IMCN 8266, 203.5 $\mathrm{mm} \mathrm{SL}(\mathrm{b})$.

Mes: mesethmoid; PP-SO: parieto-supraoccipital; TP4: transverse process of fourth vertebra; TP5: transverse process of fifth vertebra. Scale bar: $1 \mathrm{~cm}$. Photography: Anderson Cardona Ruiz. Photographic edition: Mauricio Urrego Tobón.

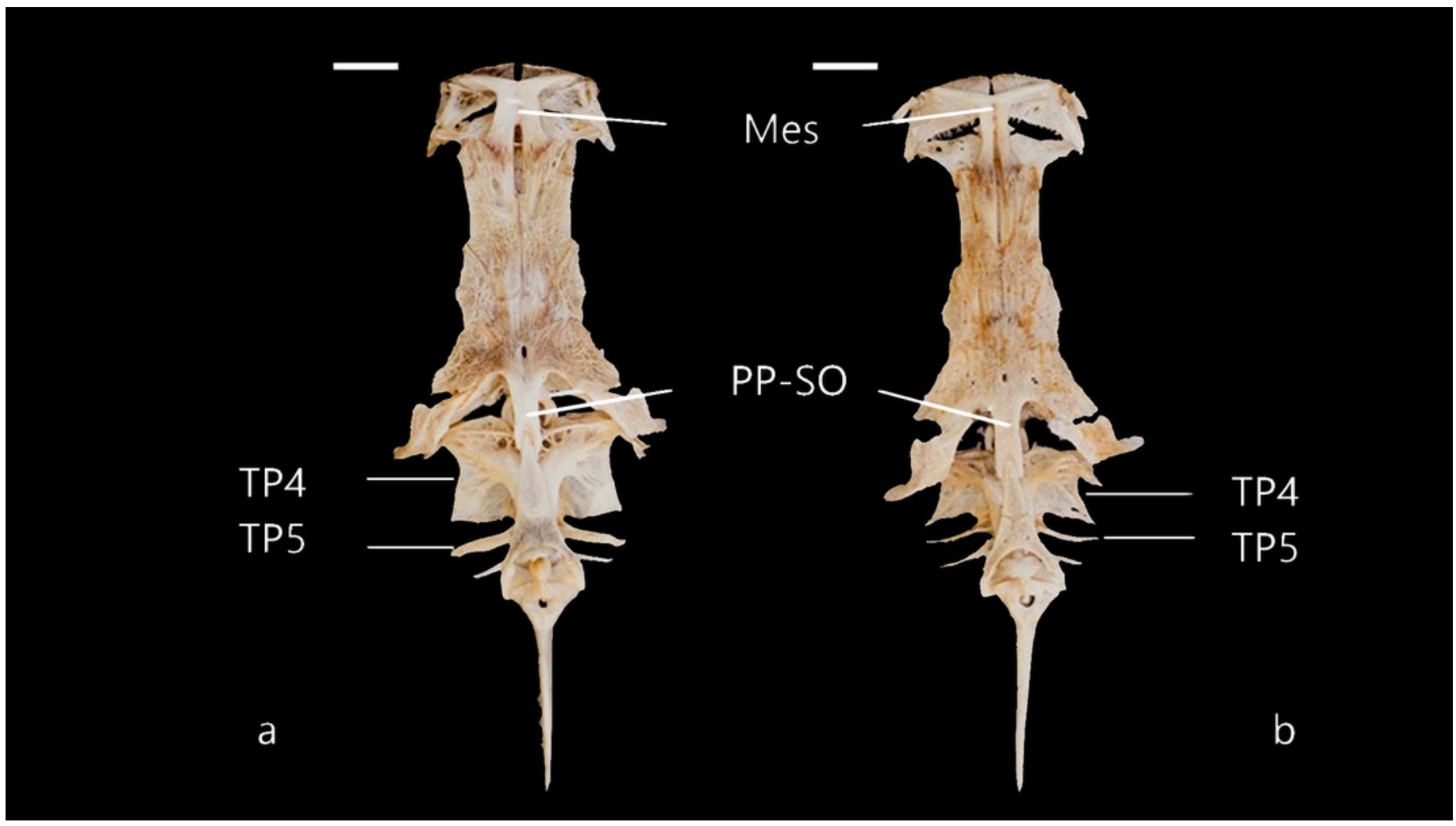




\section{Figure 6}

Gas bladder in ventral view of Pseudopimelodus magnus, IMCN 8939, $361 \mathrm{~mm} \mathrm{SL} \mathrm{(a),} P$. atricaudus, IMCN 4196, 104.1 mm SL (b) and P. bufonius, Vaupés IMCN 8230, 137.4 mm SL (c).

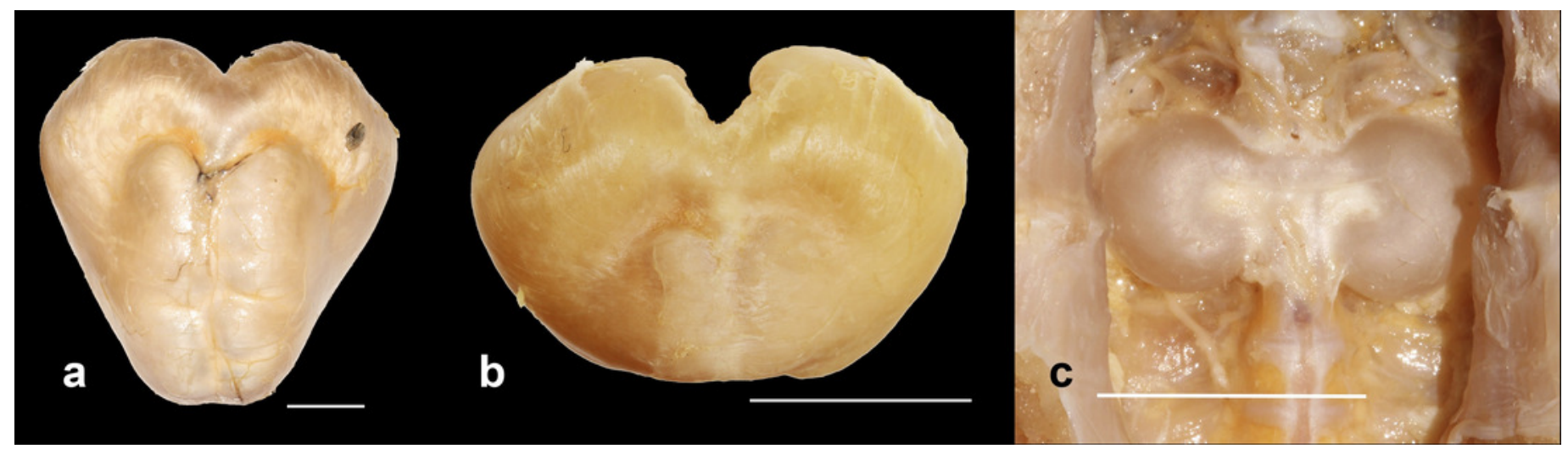




\section{Figure 7}

Live individuals of Pseudopimelodus magnus from Colombia, Antioquia, Magdalena River basin, Cauca River in Venecia.

a. Specimen not collected, showing alternative coloration pattern. b. holotype. Scale bar: 5 cm. Photography: Ana M. Restrepo Gómez. Photographic edition: Mauricio Urrego Tobón.

*Note: Auto Gamma Correction was used for the image. This only affects the reviewing manuscript. See original source image if needed for review.

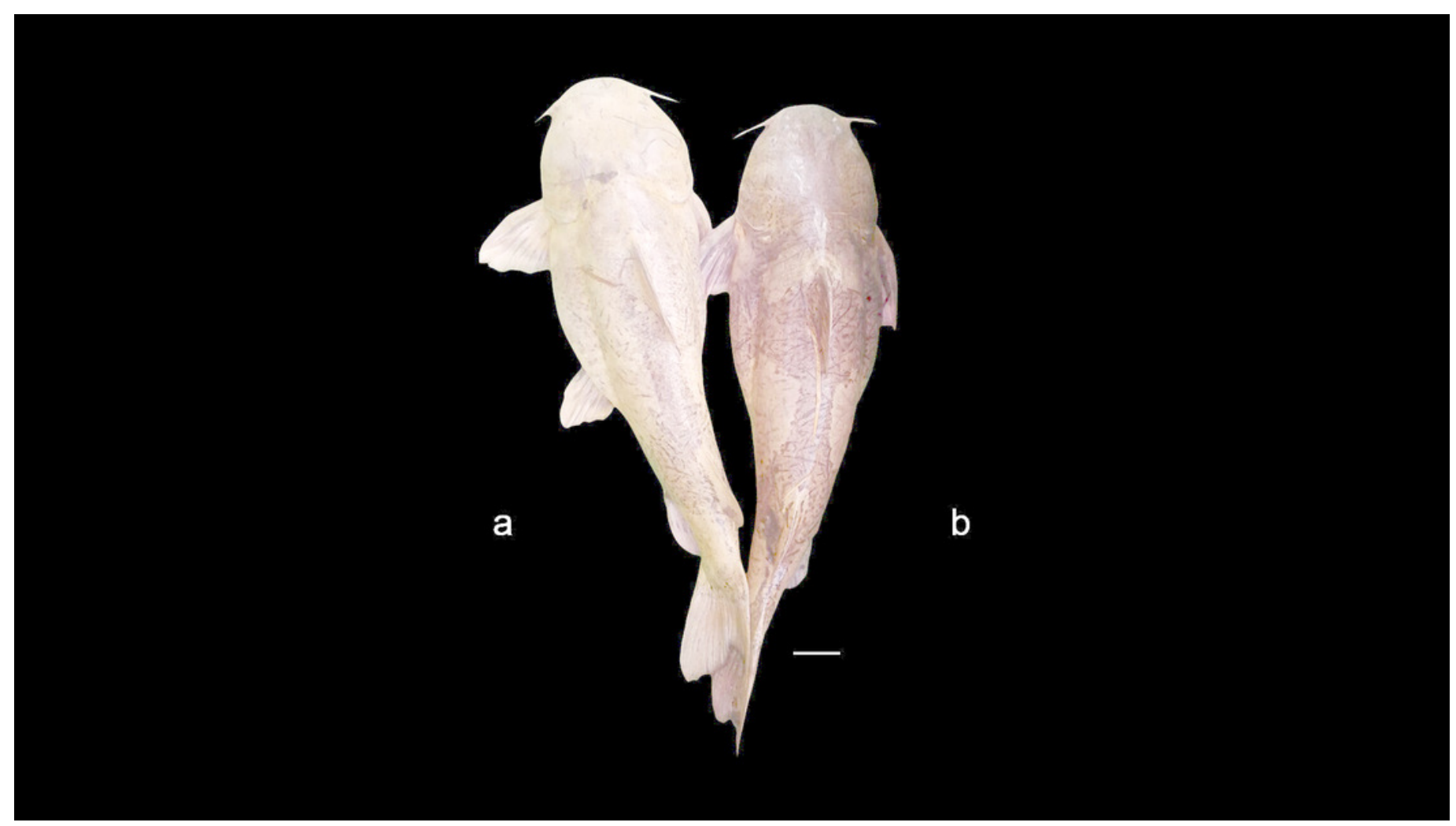


Figure 8

Map of the Magdalena-Cauca River Basin showing the geographic distribution of Pseudopimelodus magnus (circles) and P. atricaudus (stars).

Red symbols denote type locality, black symbols denote additional collection sites. Map image layer by NOAA National Centers for Environmental Information (NCEI) 


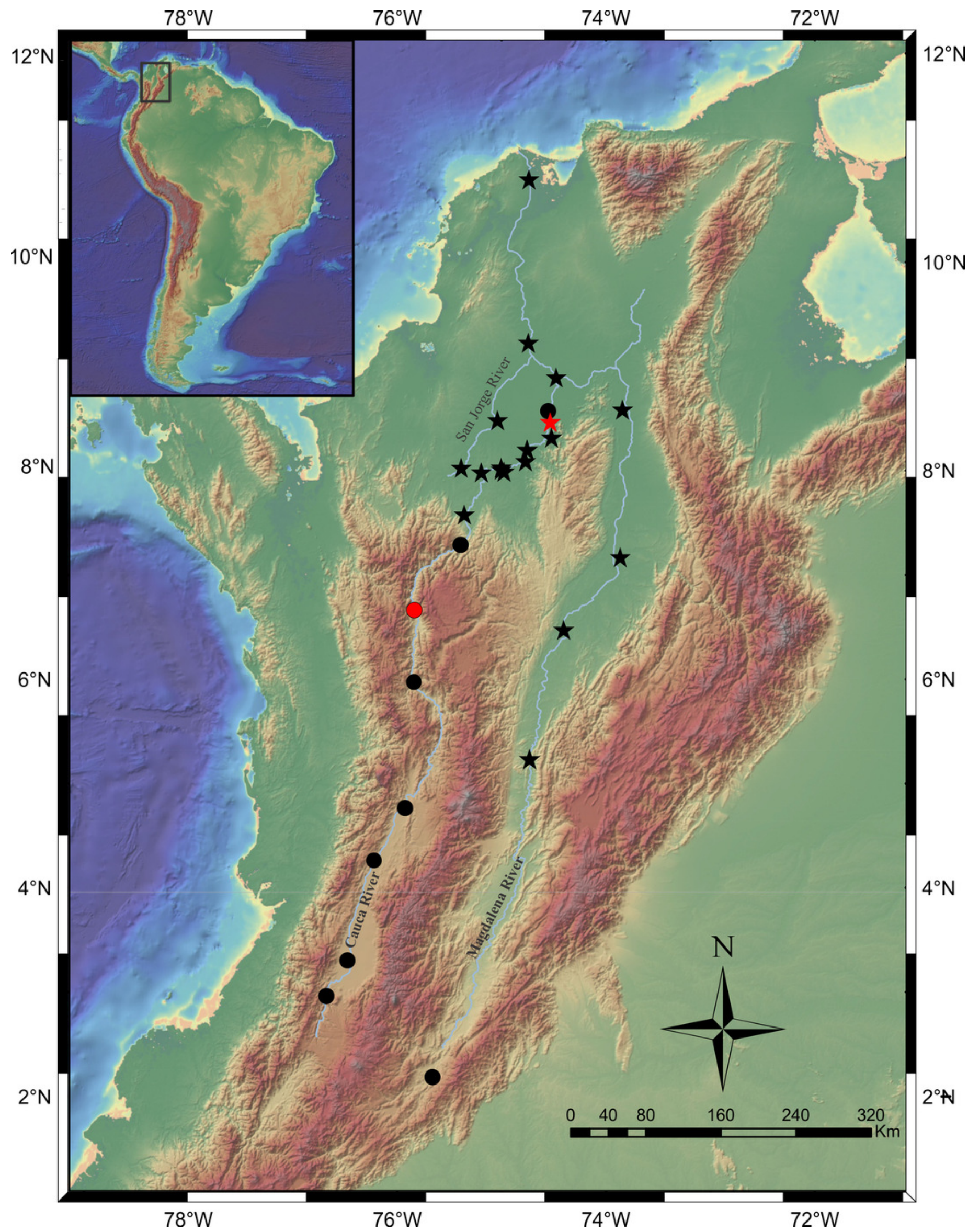




\section{Figure 9}

Pseudopimelodus atricaudus, holotype, CIUA 5141, $143.7 \mathrm{~mm} \mathrm{SL}$, Colombia, Sucre, Magdalena River basin, Cauca River in Guaranda.

a, b, c: dorsal, lateral, and ventral view, respectively. Scale bar $=1 \mathrm{~cm}$. Photography: Giovany Olaya Betancur. Photographic edition: Mauricio Urrego Tobón.

*Note: Auto Gamma Correction was used for the image. This only affects the reviewing manuscript. See original source image if needed for review. 


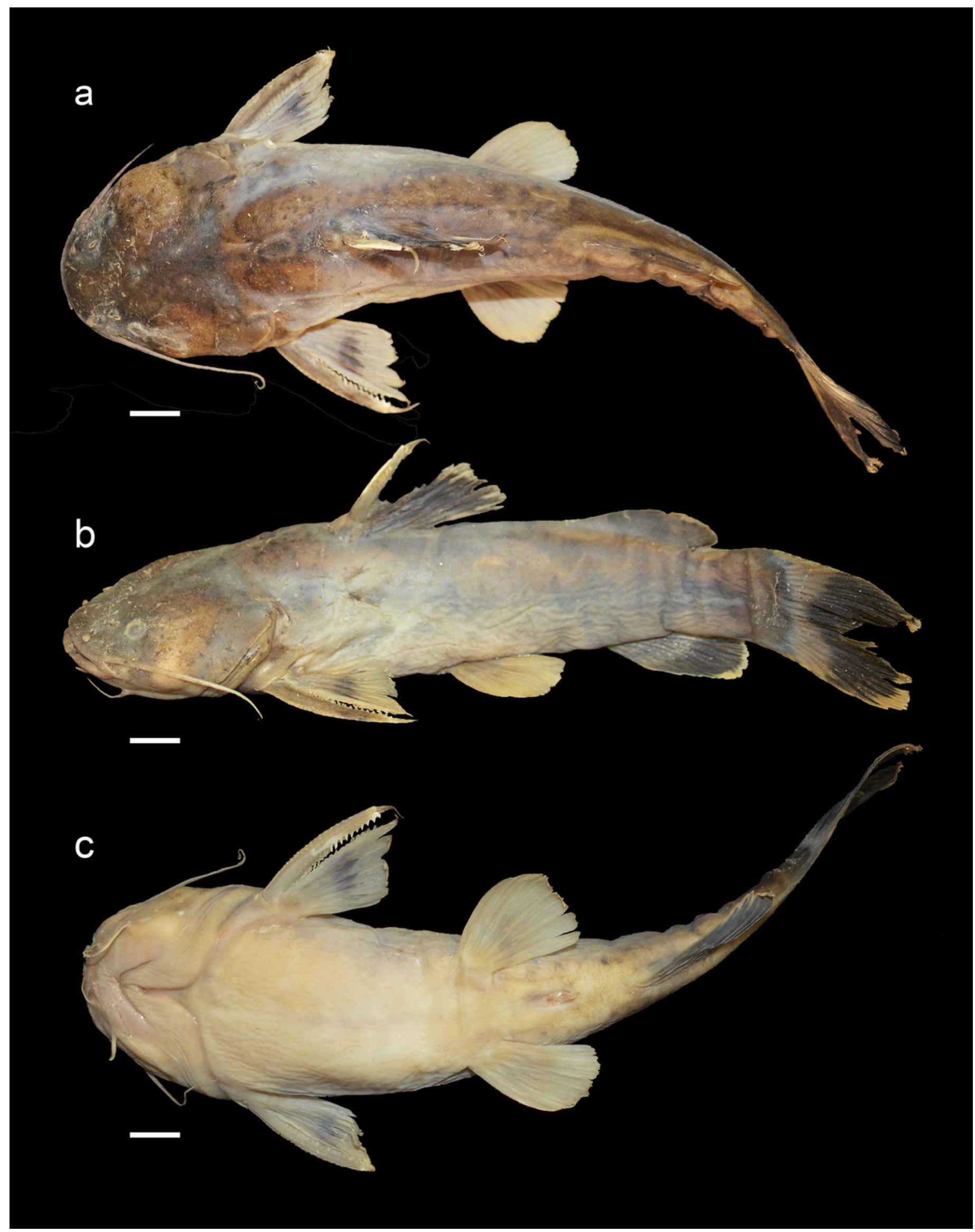




\section{Figure 10}

Dorsal-fin spine of Pseudopimelodus magnus, paratype, IMCN 8265, $213.7 \mathrm{~mm} \mathrm{SL} \mathrm{(a)}$ and $P$. atricaudus, paratype, IMCN 8266, $203.5 \mathrm{~mm} \mathrm{SL}$ (b).

Scale bar: $1 \mathrm{~cm}$. Photography: Anderson Cardona Ruiz. Photographic edition: Mauricio Urrego Tobón.

*Note: Auto Gamma Correction was used for the image. This only affects the reviewing manuscript. See original source image if needed for review.

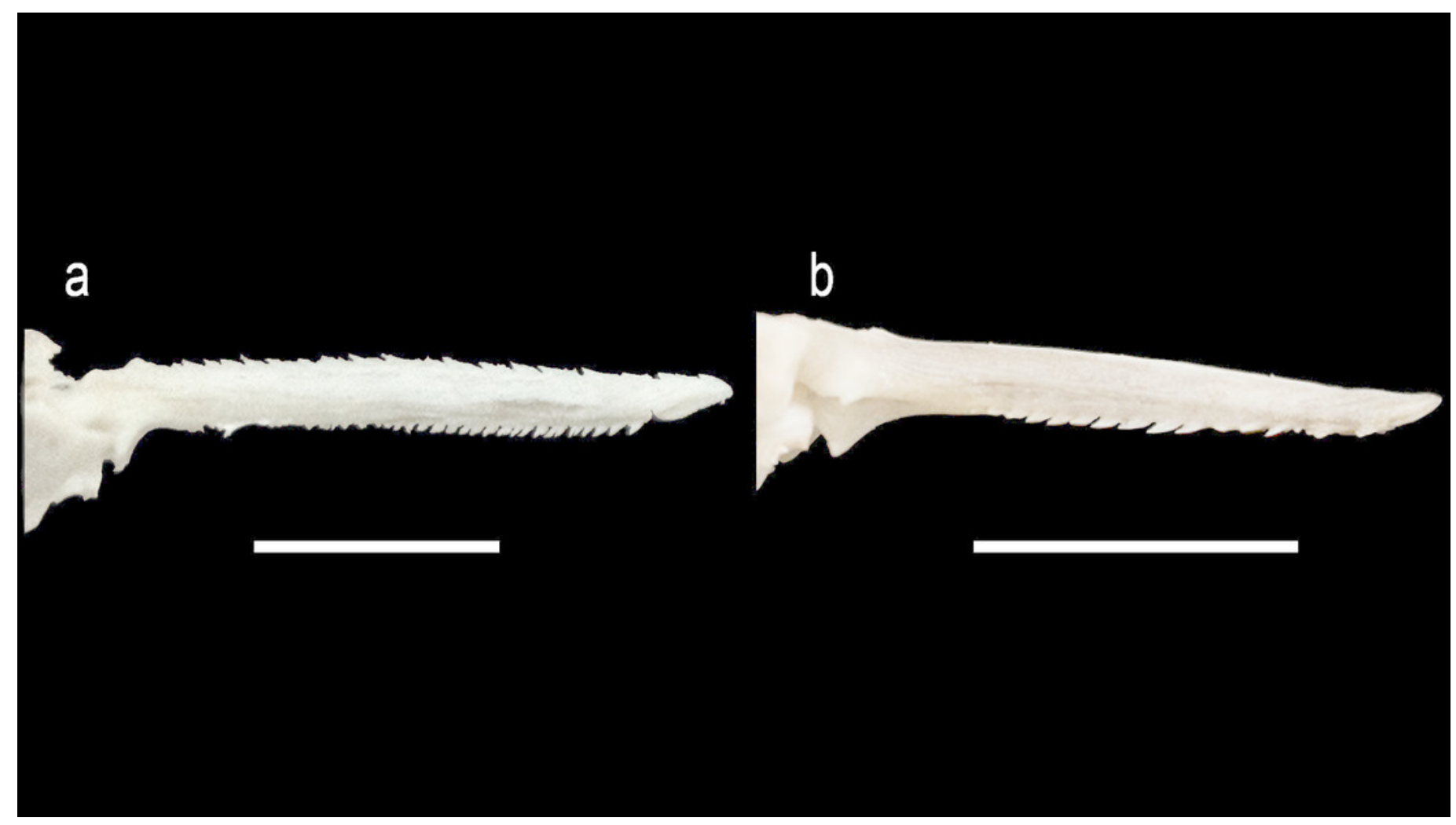




\section{Figure 11}

Juvenile live individual of Pseudopimelodus atricaudus (not collected) from Colombia, Sucre, Cauca River in Guaranda.

Scale bar: $1 \mathrm{~cm}$. Photography: Ana M. Restrepo Gómez. Photographic edition: Mauricio Urrego Tobón.

*Note: Auto Gamma Correction was used for the image. This only affects the reviewing manuscript. See original source image if needed for review.

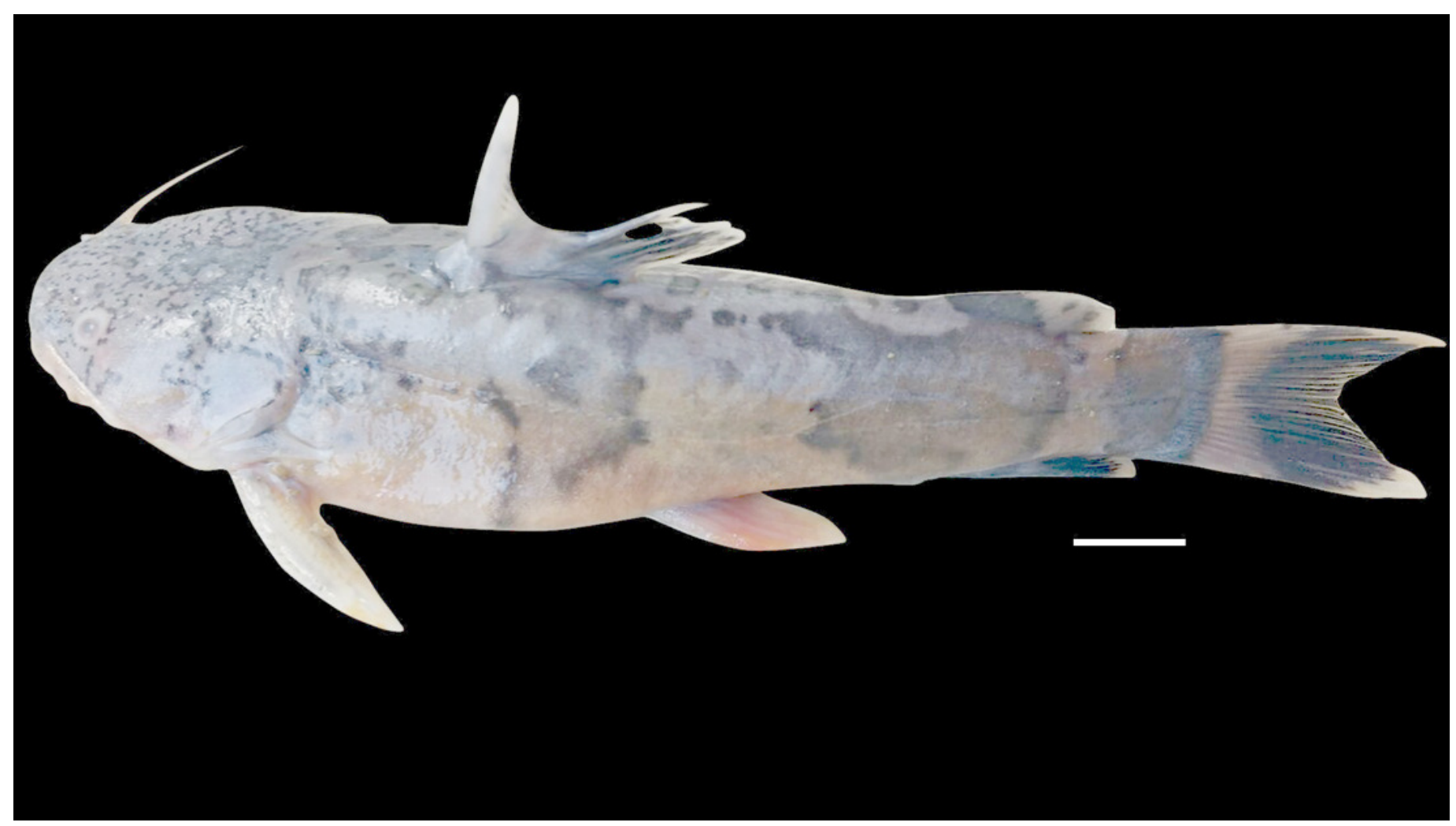

